\title{
Mapping the Human Plasma Proteome by SCX-LC-IMS-MS
}

\author{
Xiaoyun Liu, ${ }^{\text {a }}$ Stephen J. Valentine, ${ }^{\mathrm{b}}$ Manolo D. Plasencia, ${ }^{\mathrm{a}}$

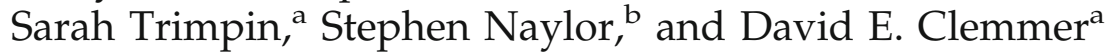 \\ ${ }^{a}$ Department of Chemistry, Indiana University, Bloomington, Indiana, USA \\ ${ }^{\mathrm{b}}$ Predictive Physiology and Medicine Inc., Bloomington, Indiana, USA
}

The advent of on-line multidimensional liquid chromatography-mass spectrometry has significantly impacted proteomic analyses of complex biological fluids such as plasma. However, there is general agreement that additional advances to enhance the peak capacity of such platforms are required to enhance the accuracy and coverage of proteome maps of such fluids. Here, we describe the combination of strong-cation-exchange and reversed-phase liquid chromatographies with ion mobility and mass spectrometry as a means of characterizing the complex mixture of proteins associated with the human plasma proteome. The increase in separation capacity associated with inclusion of the ion mobility separation leads to generation of one of the most extensive proteome maps to date. The map is generated by analyzing plasma samples of five healthy humans; we report a preliminary identification of 9087 proteins from 37,842 unique peptide assignments. An analysis of expected false-positive rates leads to a high-confidence identification of 2928 proteins. The results are catalogued in a fashion that includes positions and intensities of assigned features observed in the datasets as well as pertinent identification information such as protein accession number, mass, and homology score/confidence indicators. Comparisons of the assigned features reported here with other datasets shows substantial agreement with respect to the first several hundred entries; there is far less agreement associated with detection of lower abundance components. (J Am Soc Mass Spectrom 2007, 18, 1249-1264) (C) 2007 American Society for Mass Spectrometry

S ince Wilkins and coworkers coined the term "proteomics" in 1994 [1], there has been a significant effort to develop platform technologies for proteomic analyses [2] (for proteomic platform technology development information, see the reviews and references therein). Although spectacular progress has been made, analytical strategies for characterizing complex mixtures of proteins found in various tissues and biological fluids are still at an early stage. Even seemingly simple questions are often difficult to definitively answer, such as: how many and what proteins are present? In what quantities? Where and when do they exist in the cell, organism, or population? In the work presented below, we describe the generation of a proteome map by a multidimensional analysis that combines strong-cation-exchange (SCX), reverse-phase liquid chromatography (LC), ion-mobility spectrometry (IMS), and mass spectrometry (MS). We focus on a readily available biological fluid-human blood plasma. As discussed below, comprehensive plasma proteome characterization is arduous by any technique.

In the interest of full disclosure, one of the authors from Indiana University (DEC) is also a co-founder of Predictive Physiology and Medicine.

Address reprint requests to Dr. D. E. Clemmer, Department of Chemistry, Indiana University, 800 E. Kirkwood Ave., Bloomington, IN 47405, USA. E-mail: clemmer@indiana.edu
Our study is no exception to this. We summarize our findings in the form of a catalogue that contains 9087 protein entries; 2928 of which are high-confidence assignments, anticipated to be signals that should be reproducibly discernable with this approach. This catalogue is consistent with previous measurements for many of the more abundant species (the first several hundred proteins in our summary); there is much less consensus about lower-abundance proteins that we report (many have not been observed previously, and many that have been reported by others are not observed in this study).

In considering how many proteins are detectable in plasma, it is worthwhile to define what we mean by characterization of the plasma proteome. About 40 highly-abundant proteins found in plasma are referred to as classical plasma proteins (those with known circulatory functions) [3]; however, consideration of other sources such as tissue leakages suggests that $\sim 10^{5}$ different proteins may be present. Inclusion of splice variants suggests $>500,000$ different protein forms and perhaps $10^{7}$ immunoglobulin sequences [3]. The approach taken below, to include an additional IMS separation dimension, increases the available experimental peak capacity (compared with other multidimensional methods). This experimental measurement 
should be capable of resolving significant fractions of extremely complex mixtures [4]. However, the assignments are based on parent and fragment ion mass spectrometry (MS) results that are interpreted using the Swiss-Prot nonredundant human proteome database [5]. At the time of these experiments the database contained 11,851 protein sequences. Thus, our catalogue is restricted to this number of possible assignments.

The consideration of the large number of possible species only captures a part of the analytical problem. Abundant components such as the albumin, immunoglobulin, transferrin, apolipoprotein, haptoglobin, complement and fibrinogen proteins may be present at mg- $\mathrm{mL}^{-1}$ levels. It is estimated that the 22 most abundant proteins comprise $99 \%$ of the total protein content by mass [6], whereas species such as interleukins, involved in immune response [7], appear as minor constituents, present at $\mathrm{pg}-\mathrm{mL}^{-1}$ levels [3]. Thus, the range of concentrations spans at least nine orders of magnitude. Overall, these considerations help rationalize why a comprehensive characterization by existing analytical methods is essentially intractable.

It is paradoxical that a system that cannot be definitively defined has become a benchmark for assessing the capabilities of new instrumentation. The employment of a set of questions (e.g., How many? Which proteins can be detected in plasma?) as a standard measure of the merits of new technology, to which there is no known answer (and moreover, which must vary from sample to sample) is driven by the potential clinical importance of this sample. One of the advantages of including IMS is that it reduces chemical noise (interferences of signals that arise in congested spectra [8]); this often allows low-abundance components to be detected, even in the presence of more abundant species [9]. Although we aim to improve coverage by taking this approach, we recognize that many of the entries that are included in our map must be false assignments. In an effort to understand the threshold for truly discernable signals, we compare our assigned protein list (based on matching the Swiss-Prot database) to a list that is generated by assigning our datasets to the same database having inverted amino acid sequences. This provides a measure of the rate of random assignments but does not illuminate which assignments are expected to be false. Future experiments will be necessary to corroborate those features that are reproducibly detected.

Although most of the components that exist in plasma may not have been identified, some features are definitively known. Studies using two-dimensional gel electrophoresis provided much of the early knowledge of the more abundant plasma proteins [10-12]. Analysis by this method can be traced back to the 1970s [3, 13, $14]$, and $\sim 60$ proteins (primarily the classical plasma proteins) had been identified by 1992 [15]. In the last decade, shotgun proteomics utilizing LC and SCX-LC combined with MS detection and database assignment techniques emerged as a powerful means of characterizing complex protein mixtures [16-18]. These methods dramatically increased the number of observable pro- teins (and also reduced the time for analysis) [6, 19-22]. It is now common to identify hundreds of proteins from plasma for a single sample [23-25]. Several studies report even greater coverage [21, 24-26].

With such rapid progress in characterizing a sample about which so little is known, it is important to develop standard procedures for comparing findings. Many factors limit the comparison of plasma proteome analyses, including: differences in methods of sample procurement and preparation [25, 27-30]; incomplete sampling associated with ion selection and dissociation methods associated with MS analysis [21, 31-37]; limitations in instrumental dynamic range [21, 38, 39]; early developmental stage of the algorithms and databases used for protein assignment [40,41]; as well as actual differences in composition between plasma samples [3, 9, 15, 21, 39]. An impression about the extent of the variability that exists can be gleaned from Anderson et al.'s 2004 summary of the reported literature from four sources [15]. This summary included a single nonredundant protein list of 1175 unique proteins; however, only 46 were detected from all four different sources. More recently, a core dataset of 3020 plasma proteins was generated by a cooperative effort known as the plasma proteome project [directed by the Human Proteome Organization, (HUPO)] [25]. This more comprehensive dataset is a compilation of results from 35 laboratories (and other analytical groups) and allows for statistical evaluation by others [42]. Of those proteins reported in the plasma proteome project summary (the 3020 core dataset), 316 are found in Anderson's 1175 nonredundant list [25].

In 2006, our group reported a method designed to increase the throughput of comprehensive plasma proteome analyses [9]. In that work, we introduced IMS separation to reduce the total time required for twodimensional LC analysis. We found evidence for 438 proteins. Here, we extend the 2006 study by carrying out a more extensive two-dimensional LC analysis (and inclusion of an abundant protein removal step) on samples from five healthy (normal) individuals. This more comprehensive effort increases proteome coverage.

The present work involving IMS measurements builds on advances in instrumentation and theory. During the last $15 \mathrm{y}$, fundamental work that makes the present work possible has been done, including: coupling of new ion sources to mobility instruments [4349]; improvements in ion focusing [47, 50-53], detection limits [53-55], and instrumental resolution [56-58]; methods for predicting mobilities [59-62]; as well as comparing measurements with mobility calculations [63-65] (for trial geometries generated by theory) to characterize ion structure [66-68]. Although we have not included such an analysis here, the ability to check assignments by comparison of experimental and theoretical mobilities is likely to have substantial value in reducing false assignments. The format of the map that is presented includes experimental parameters, as well as drift times, ion charge states, and sequences, so that 


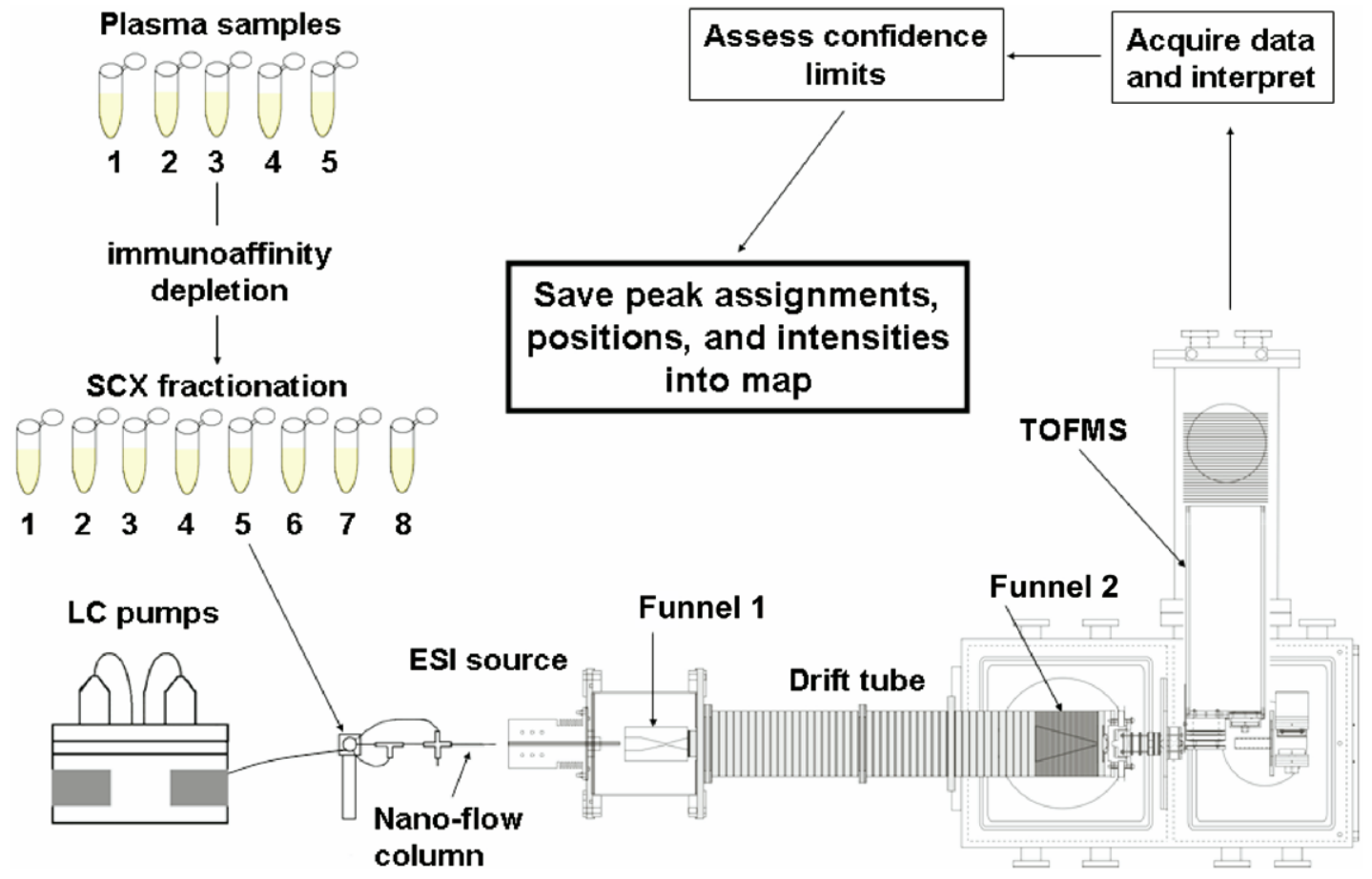

Figure 1. Schematic representation of the experimental protocol used to generate the plasma proteome map. In many ways this analysis is analogous to other SCX-LC-MS/MS methods. The difference is found in the inclusion of a split-field drift tube for IMS separation and the use of field modulation for generation of fragment spectra. See text and references therein for details.

such comparisons can be conducted on this dataset in the future.

One final point is important. Although we report 9087 proteins, of which 2928 meet our criteria as highconfidence assignments, we believe that at this early stage the best use of these data is as a means of testing new analytical technologies. It is difficult to resist the temptation to check to see if potential disease markers found from analysis of tissues are detectable in plasma; however, in our opinion, any such comparison (with this or other extensive plasma lists) should be done cautiously.

\section{Experimental}

\section{General}

A schematic showing the overall process associated with characterizing the plasma proteome is provided as Figure 1. The individual steps in this process, described in detail below, are as follows: (1) acquire plasma proteins from blood samples and enzymatically digest this mixture to produce tryptic peptides; (2) fractionate the mixture of peptides using SCX; (3) record triplicate analyses of each fraction using a home built LC-IMS-MS setup; (4) find all peaks associated with precursor ion MS and fragment ion MS datasets; (5) compare all MS peaks against a database of expected protein sequences for identification; and (6) cull together information about interpreted peaks to produce the proteome map.
With the exception of LC columns and pumping systems (Step 2 and partially Step 3) and the algorithms used for protein (all of Step 5), all instrumentation and software are home built.

We often refer to multidimensional measurements or datasets as nested. This term was chosen in the first paper that describe IMS-MS measurements that took advantage of the fact that flight times in the evacuated MS instrument are much shorter than the time required for ions to drift through the buffer gas (in the IMS experiment). Such a case has a theoretical advantage compared with scanning (or selected ion) approaches in that all components are (in theory) subjected to the same analysis. In the present work, the time scales are such that the MS measurement $(\mu s)$ is nested within the IMS separation (ms); the IMS separation is nested within the LC measurement (s); and, the LC measurement is nested within the SCX separation.

\section{Acquisition of Plasma Samples}

Whole blood ( $2 \mathrm{~mL}$ ) was drawn by a trained phlebotomist using standard venipuncture techniques. Ethylene diamine tetra-acetic acid (Vacutainer no. 367899, Becton, Dickinson \& Company, Franklin Lakes, NJ) was used as the anticoagulant agent. The blood sample was then centrifuged at $4000 \mathrm{rpm}$ to obtain platelet poor plasma. Blood sample collection and analyses have 
been carried out under the auspices of current, approved institutional review board protocols [69].

\section{Depletion of Abundant Proteins}

Abundant proteins are depleted using the Agilent high capacity multiple affinity removal system (MARS; Agilent Technologies, Inc., Palo Alto, CA), which consists of an LC column $(4.6 \times 100 \mathrm{~mm})$ that utilizes antigenantibody interactions to remove six abundant plasma proteins: albumin, IgG, IgA, transferring, haptoglobin, and antitrypsin [70]. ${ }^{\circ}$ From $^{\circ} \sim 500^{\circ} \mu \mathrm{L}^{\circ}$ of ${ }^{\circ}$ plasma ${ }^{\circ} 90^{\circ} \mu \mathrm{L}$ aliquots are diluted with the addition of $270 \mu \mathrm{L}$ of buffer A and filtered through a $0.22 \mu \mathrm{m}$ spin filter (Agilent) to remove particulates before injection onto the column. A high-pressure LC (600 series pump; 2487 dual $\lambda$ detector, Waters, Inc, Milford, MA) is operated as follows: $100 \%$ buffer A at a flow rate of $0.5 \mathrm{~mL}-\mathrm{min}^{-1}$ for $10 \mathrm{~min}$ followed by $100 \%$ B for $7 \mathrm{~min}$ at 1.0 $\mathrm{mL}-\mathrm{min}^{-1}$ to elute the bound fraction containing the six abundant proteins. The flow-through fraction containing low-abundance proteins is collected between 2.0 and $6.0 \mathrm{~min}$. The column is regenerated by equilibrating with buffer A for $11 \mathrm{~min}$ at a flow rate of $1.0 \mathrm{~mL}-\mathrm{min}^{-1}$. Elution of proteins is monitored at $\lambda=280 \mathrm{~nm}$. Successive aliquots are introduced onto the MARS column until the original $500 \mu \mathrm{L}$ sample is consumed.

\section{Enzymatic Digestion of the Plasma Protein Mixture to Create Mixtures of Peptides}

Mixtures of proteins are digested with trypsin to produce mixtures of peptides. This approach is referred to as a bottom-up approach and is essentially done to make it possible to generate ions that will produce useful precursor-ion and fragment-ion datasets. To obtain tryptic peptides, the flow-through fraction is concentrated with a $4.0 \mathrm{~mL}$ Vivaspin $5 \mathrm{~K}$ Da MWCO membrane concentrator (Agilent Technologies). A subsequent Bradford assay experiment is performed and typically samples are found to contain $\sim 4 \mathrm{mg}$ total plasma protein. The sample is then added to $10.0 \mathrm{~mL} 0.2$ $\mathrm{M}$ Tris buffer containing $8 \mathrm{M}$ urea along with $10.0 \mathrm{mM}$ $\mathrm{CaCl}_{2}$. Disulfide bonds are reduced by addition of dithiothreitol (DTT) at a molar ratio of 40:1 (DTT: protein) and incubated at $37^{\circ} \mathrm{C}$ for $2 \mathrm{~h}$. After reduction, the sample is cooled to $0^{\circ} \mathrm{C}$ on ice and iodoacetamide (IAM) is added at a molar ratio of 80:1 (IAM:protein) and left for another $2 \mathrm{~h}$ in darkness. Excess cysteine (40-fold excess) is added at room temperature to react with any residual DTT and IAM for $30 \mathrm{~min}$. The sample is then diluted with $0.2 \mathrm{M}$ Tris buffer $(\mathrm{pH}=8.0)$ until the urea concentration is $2 \mathrm{M}$. Finally, $2 \%(\mathrm{wt} / \mathrm{wt})$ TPCK-treated trypsin (Sigma-Aldrich) is added to the solution and digestion is allowed to occur for $24 \mathrm{~h}$ at $37^{\circ} \mathrm{C}$. The resulting tryptic peptides are desalted with an Oasis HLB cartridge (Waters Inc.) and dried on a centrifugal concentrator.

\section{Strong-Cation Exchange (SCX) Fractionation}

The separation column $(100 \times 2.1 \mathrm{~mm})$ is packed with 5 $\mu \mathrm{m} 200$ Å Polysulfethyl A (PolyLC Inc., Columbia, MD) and installed on the same LC system as described above. Dried peptides are reconstituted in $500 \mu \mathrm{L}$ buffer SCX1 and passed through a $0.22 \mu \mathrm{m}$ spin filter before being loaded onto the column. The flow rate is kept at $0.2 \mathrm{~mL} \mathrm{~min}^{-1}$, and the sample is fractionated using a two buffer system [buffers SCX1 and SCX2 were prepared as follows: SCX1. $5 \mathrm{mM} \mathrm{KH} \mathrm{PO}_{4}$ in 75:25 water: acetonitrile $(\mathrm{pH}=3)$ and SCX2. $5 \mathrm{mM} \mathrm{KH}_{2} \mathrm{PO}_{4}, 0.35 \mathrm{M}$ $\mathrm{KCl}$ in $75: 25$ water:acetonitrile $(\mathrm{pH}=3)]$. The following gradient is employed: $0 \%$ buffer SCX2 for $5 \mathrm{~min}, 0 \%$ to $40 \%$ buffer SCX2 in $40 \mathrm{~min}, 40 \%$ to $80 \%$ buffer SCX2 in $45 \mathrm{~min}, 80 \%$ to $100 \%$ buffer SCX 2 in $10 \mathrm{~min}, 100 \%$ buffer SCX2 for $10 \mathrm{~min}, 100 \%$ to $0 \%$ buffer SCX2 in $15 \mathrm{~min}$, and $0 \%$ buffer SCX2 for $10 \mathrm{~min}$. Eluting peptides are monitored at both 210 and $280 \mathrm{~nm}$. Eluent is collected manually over 1-min intervals with a 96-well plate. Individual wells are pooled into eight fractions based on the absorbance profile of the eluted peptides. All fractions are desalted with HLB cartridges and dried before LC-IMS-MS analysis.

\section{Nanoflow Reverse-Phase LC}

The nanoflow reverse-phase LC separation is carried out with an Agilent 1100 Series CapPump (Agilent Technologies) equipped with a homemade nanocolumn $(75 \mu \mathrm{m} \times 150 \mathrm{~mm})$ as well as a packed trapping column $(100 \mu \mathrm{m} \times 15 \mathrm{~mm})$. The tip at the end of the $75 \mu \mathrm{m}$ fused capillary (Polymicro Technology LLC, Phoenix, AZ) is pulled with a microflame torch and packed with a methanol slurry of $5 \mu \mathrm{m}, 100 \AA$ Magic C18AQ (Microm BioResourses Inc., Auburn, CA) at a constant pressure $(1000 \mathrm{psi})$. The trapping column $(1.5 \mathrm{~cm})$ is packed in a $100 \mu \mathrm{m}$ capillary with an integral frit (New Objective Inc., Woburn, MA) using a slurry of $5 \mu \mathrm{m}, 200$ $\AA$ Magic C18. The trapping column is employed before the analytical column and used to preconcentrate and desalt the sample. Dried peptides are reconstituted in HPLC water and an aliquot of $10 \mu \mathrm{L}$ of sample is introduced onto the column. A binary gradient with Solvent A $\left(97 \% \mathrm{H}_{2} \mathrm{O}, 3 \% \mathrm{ACN}\right.$, and $0.1 \%$ formic acid) and Solvent $\mathrm{B}\left(3 \% \mathrm{H}_{2} \mathrm{O}, 97 \% \mathrm{ACN}\right.$, and $0.1 \%$ formic acid) is employed as the mobile phase with the following gradient sequence: Solvent B is ramped up from $6 \%$ to $30 \%$ in $100 \mathrm{~min}$ and then increased to $38 \%$ over 20 min. Subsequently, Solvent B is rapidly increased to $90 \%$ over $10 \mathrm{~min}$ and maintained for $15 \mathrm{~min}$ to elute the highly retained species. Finally the gradient is changed to $0 \%$ Solvent B immediately and held for another 15 min to equilibrate the column.

\section{IMS-MS Measurements}

The ${ }^{\circ M S-M S}$ instrument ${ }^{\circ}$ shown $^{\circ}$ in ${ }^{\circ}$ Figure $^{\circ}{ }^{\circ}$ is $^{\circ}$ similar ${ }^{\circ}$ to others $^{\circ}$ described $^{\circ}$ in $^{\circ}$ detail $^{\circ}$ elsewhere $\left[9,{ }^{\circ} 71,{ }^{\circ} 72\right] .^{\circ} \mathrm{How}-$ 
ever, there are some differences that address issues associated with ion storage and transmission in the mobility device. An ion funnel (hour-glass geometry), similar ${ }^{\circ}$ to $^{\circ}$ one $^{\circ}$ described $^{\circ}$ by $^{\circ}$ Smith $^{\circ}$ and ${ }^{\circ}$ coworkers,,$[50$, $\left.51,{ }^{\circ} 53\right]^{\circ}{ }^{\circ}{ }^{\circ}{ }^{\circ}$ been $^{\circ}$ employed ${ }^{\circ}$ for ${ }^{\circ}{ }^{\circ}{ }^{\circ}$ accumulation ${ }^{\circ}$ before the drift tube. This geometry is employed to increase storage ${ }^{\circ}$ capacity $^{\circ}$ and $^{\circ}$ overall ${ }^{\circ}$ sensitivity ${ }^{\circ}[53] .{ }^{\circ}$ Additionally, a second ion funnel has been incorporated near the exit region of the drift tube before the TOF source region ${ }^{\circ}{ }^{\circ}{ }^{\circ}$ mprove ${ }^{\circ}{ }^{i o n}{ }^{\circ} \operatorname{transmission}^{\circ}[53]$.

The overall experimental sequence associated with the IMS-TOF analysis is as follows. Electrosprayed peptides are introduced into an hour-glass ion funnel where ions are stored and pulsed into the drift tube for mobility separation. The drift tube utilizes a split-field $\operatorname{design}^{\circ}[71]^{\circ}$ that ${ }^{\circ}$ allows ${ }^{\circ}$ either ${ }^{\circ}$ transmission ${ }^{\circ}$ or $^{\circ}$ fragmentation of precursor ions depending on the applied voltages at the drift exit region. The first field region is $70.4 \mathrm{~cm}$ long. Ions drift through $3.20 \pm 0.05$ torr of $300 \mathrm{~K}$ $\mathrm{N}_{2}$ :He buffer gas (1:16 blend) under the influence of a uniform field $\left(12.6 \mathrm{~V} \mathrm{~cm}^{-1}\right)$ and are separated based on differences in their mobilities. As has been described previously, ${ }^{\circ} \mathrm{drift}^{\circ}$ times $^{\circ}$ are $^{\circ}$ highly $^{\circ}$ reproducible $^{\circ}\left[9,{ }^{\circ} 66\right.$, 67]..$^{\circ}$ Ions $^{\circ}$ with $^{\circ}$ more $^{\circ}$ compact $^{\circ}$ structures $^{\circ}$ tend $^{\circ}$ to ${ }^{\circ}$ have higher mobilities (undergo fewer collisions with the buffer ${ }^{\circ}$ gas $)^{\circ}$ than $^{\circ}{ }^{\circ}$ ions ${ }^{\circ}$ with $^{\circ}$ extended $^{\circ}$ structures ${ }^{\circ}\left[66^{\circ}-88\right.$, 73]. ${ }^{\circ}$ Additionally, ${ }^{\circ}$ ions ${ }^{\circ}$ with $^{\circ}$ higher $^{\circ}$ charge $^{\circ}$ states $^{\circ}$ typically have higher mobilities than ions with low charge states $^{\circ}$ because $^{\circ}$ they $^{\circ}$ experience $^{\circ} a^{\circ}$ larger $^{\circ}$ drift $^{\circ}$ force $^{\circ}[74$, 75].

The second drift region is relatively short $(\sim 1 \mathrm{~cm}$ long). The electric field in this region is alternated between conditions that favor precursor ion transmission or fragmentation via collision-induced dissociation $(\mathrm{CID})^{\circ}[71] .{ }^{\circ}$ Modulation $^{\circ}$ is $^{\circ}$ achieved $^{\circ}$ with $^{\circ}$ fast $^{\circ}$ high- $^{-}$ voltage operational amplifiers (Apex Microtechnology, Tucson, AZ). Upon exiting the drift tube, mobility dispersed ions are extracted orthogonally into the source region of a reflectron time-of-flight MS instrument for mass to charge $(\mathrm{m} / \mathrm{z})$ analysis.

\section{Nomenclature for Peak Positions and Data Analysis}

The positions of individual peaks are determined using an algorithm written in-house and can be described by a nomenclature that incorporates the concept of the nested ${ }^{\text {'measurement }}$ [76]. We'report ${ }^{\circ}{ }^{\circ}$ ' retention times $\left(t_{R}\right)$, IMS drift times $\left(t_{D}\right)$, and MS $m / z$ values (obtained from flight times) for features observed in the dataset as $t_{R}\left[t_{D}(m / z)\right]$ in units of $\min [\mathrm{ms}(m / z)]$. SCX information is included as $t_{S C X}$, referring to the SCX fraction number such that any peak can be defined as $t_{S C X}\left\{t_{R}\left[t_{D}(m / z)\right]\right\}$.

We begin data analysis by processing the raw data with software developed in-house to determine the positions and intensities associated with peaks found in the multidimensional space. Once a multidimensional peak and intensity list has been generated, $m / z$ values (associated with modulated measurements) having peaks with identical values of $t_{S C X}, t_{R}$, and $t_{D}$ are grouped together to effectively assemble parent and fragment mass spectra. These data are then converted into DTA files (SEQUEST, Thermo Finnigan, Waltham, MA), which are submitted for query against the SwissProt protein database (release 20050201) using the suite of MASCOT software (Matrix Science Ltd. London, UK) $\left[77,{ }^{\circ} 78\right] .{ }^{\circ} Q^{Q}$ ueries $^{\circ}$ that $^{\circ}$ lead $^{\circ}$ to $^{\circ}$ scores $^{\circ}$ that $^{\circ}$ are $^{\circ}$ above ${ }^{\circ}$ the extensive homology or identity threshold are saved as possible peptide assignments. These preliminary assignments are subjected to a set of additional criteria, including the number of fragments observed for a given ion type (such as b- or y-series ions) and information about the fragment ion mass accuracy that is used to remove obvious false positives. The peak positions and intensities of those peptides that meet the assignment criteria are compiled into a searchable database (the initial proteome map). The entire data analysis is automated and has been optimized with the use of a 24 node dual CPU (IBM e326) cluster.

\section{Results and Discussion}

\section{Considerations Associated with Inclusion of an IMS Separation Dimension}

It is worthwhile to summarize some of the strengths and weaknesses associated with including an IMS separation dimension for plasma proteome analysis. From an experimental perspective, the increase in peak capacity that is obtained occurs on a very rapid time scale (ms) such that there is no increase in the time associated with LC-IMS-MS data acquisition compared with LC-MS. The increase in peak capacity reduces spectral congestion and leads to an increase in the ability to resolve peaks. Thus, from the perspective of profiling it is an attractive approach.

The modulation method that we employ allows the generation of fragment ions for distributions of ions in $\mathrm{a}^{\circ}$ parallel $^{\circ}$ fashion $^{\circ}\left[71,{ }^{\circ} 79\right] .^{\circ}$ In $^{\circ}$ some $^{\circ}$ ways $^{\circ}$ this $^{\circ}$ is ${ }^{\circ}$ an advantage as well. For example, in cases where many species co-elute from the LC column, there may not be adequate time to select all of them for MS/MS analysis. Also, MS/MS methods run into difficulties in selecting low-intensity features that are near (or below) the baseline of the parent ion MS measurement. The modulated approach that we employ makes it possible to observe many of these types of ions that would be missed with conventional MS/MS methods. This said, the dearth of a formal MS selection step for fragment ion analysis is often a significant disadvantage. For such complex mixtures, it is often the case that multiple precursor ions are present even after SCX, LC, and IMS separations, and in such cases the fragment distributions that are formed in the high-energy modulation approach used in the IMS approach will include fragments from a mixture of precursors that are present. This complicates the identification and assignments of 
peaks (and ultimately makes the false positive rate of this approach somewhat higher than MS/MS based methods).

A final note before discussing the data and the map is associated with analysis of datasets. A major bottleneck that comes about from including an IMS separation is that datasets are much larger than those obtained without this dimension (additionally there are no commercially available algorithms for analysis). Although there is an advantage associated with the fact that the additional peak capacity comes at no additional cost in time required to acquire data (with and without IMS separation), there is a disadvantage associated with computing time associated with analysis.

\section{Example Plots of SCX-LC-IMS-MS Data}

Figure ${ }^{\circ}{ }^{\circ}$ shows ${ }^{\circ}$ several ${ }^{\circ}$ representations ${ }^{\circ}$ of $^{\circ}$ various $^{\circ}$ parts of the multidimensional dataset. We begin by plotting the recorded ion intensity obtained for bins associated with the LC and IMS dimension for a single SCX fraction $^{\circ}$ of ${ }^{\circ}$ one $^{\circ}$ of $^{\circ}$ the $^{\circ}$ samples $^{\circ}\left(\right.$ Figure $\left.^{\circ} 2 a\right) .^{\circ}$ This $^{\circ}$ plot shows that there is a broad distribution of ions that are observed from $\sim 30$ to $100 \mathrm{~min}$. A clear feature of this plot $^{\circ}\left(\right.$ Figure $\left.^{\circ} 2 \mathrm{a}\right){ }^{\circ}$ is $^{\circ}$ that $^{\circ}$ peptides $^{\circ}$ co-elute ${ }^{\circ}$ over $^{\circ}$ most $^{\circ}$ of the LC-separation time. While it is not apparent from this representation of the data, we note that except for the leading and trailing edges of the IMS dimension, multiple ions are observed at essentially every drift time as well. Examination of these data leaves us with the impression that even the three-dimensional SCXLC-IMS separation is far less than what would be required to isolate components before introduction into the mass spectrometer.

An impression about the resolution and peak capacity associated with these dimensions of separation can be obtained from a two-dimensional $t_{R}\left(t_{D}\right)$ base-peak ${ }^{\circ}$ plot $^{\circ}\left(\text { Figure }^{\circ} 2 b\right)^{\circ}$ derived $^{\circ}$ from $^{\circ} \mathrm{a}^{\circ}$ single LC-IMS-MS analysis. This plot shows only the most intense peaks across all flight times. A significant advantage of this type of plot is that it shows the importance of including an ion mobility dimension. Many different ions have identical retention times. From the widths of peaks in each dimension, and the range over which they are observed, we estimate the experimental two-dimensional LC-IMS peak capacity to be $\sim 6000$ to 9000 .

Figure $^{\circ} 2^{\circ}$ also $^{\circ}$ shows $^{\circ} \mathrm{a}^{\circ}$ plot $^{\circ}$ of ${ }^{\circ}$ the ${ }^{\circ}$ intensities ${ }^{\circ}$ and positions of peaks as they are projected onto only the LC axis. This provides additional insight about the relationship of sample complexity to experimental peak capacity. In this case essentially all features that are observable in the LC dimension are comprised of many peaks.

\section{Reproducibility of Identified Peptide Positions}

It is important to assess the reproducibility of peaks. Analysis of data for assignments obtained from sequen- tial triplicate runs of a single sample shows that peptide ion peak positions within the multidimensional dataset are highly reproducible. Along the $t_{R}$ and $t_{D}$ dimensions, the percent relative uncertainty in position (from three analyses) is $1 \%$ and $2 \%$, respectively. A similar comparison of the same peaks for three different samples yields a reproducibility of $4.8 \%$ and $2 \%$ for these respective dimensions. Note that the position of a peak in the drift time dimension does not vary for different samples.

\section{Accumulation of the Plasma Proteome Map}

Peaks associated with peptide ions from the SCX-LCIMS-MS datasets are identified by combining information from the precursor MS spectra with the CID-MS ${ }^{\circ}$ spectra. ${ }^{\circ}$ Figure $^{\circ} 3^{\circ}$ shows $^{\circ}$ examples $^{\circ}$ of ${ }^{\circ}$ three typical CID-MS spectra (at specific values of $t_{S C X}, t_{R}$, and $t_{D}$, for fragment ions; precursor data not shown). Upon analysis, the overall assignments are consistent with peaks that correspond to primarily y-type and b-type ions for three peptide sequences (VSFLSALEEYTK, DSVTGTLPK, and VEVVDEER) that are unique to three different proteins (apolipoprotein A-I, kallikrein, and troponin I, respectively). These data and assignments are typical of most of the features that are assigned in our datasets. We have focused on these three assignments because they allow some insight about the dynamic range associated with the raw data as well as the experiment. The plots have been normalized and so, as indicated in the figure, the peaks assigned to apolipoprotein are a factor of 400 times more intense than those for troponin I. This is consistent with the large difference in concentrations expected for these proteins $(\sim \mathrm{mg}$ $\mathrm{mL}^{-9^{\circ}}$ to $^{\circ} \mathrm{ng}^{\circ} \mathrm{mL}^{-9^{\circ}}$ for ${ }^{\circ}$ these ${ }^{\circ}$ respective ${ }^{\circ}$ proteins $\left.{ }^{\circ}[80]\right)$. The concentration of kallikrein is reported to be in the

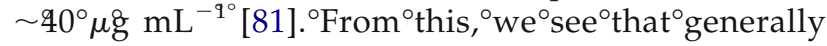
the intensities of assigned features are qualitatively ordered in a fashion that reflects the concentrations of proteins (in cases where such data exists). However, there is a large mismatch associated with the range of measured intensities compared with the range of known concentrations. This may reflect the fact that some low abundance components are falsely assigned as we dig into the low-intensity features of our datasets for database searches. An alternative explanation is that variations in physical properties (e.g., ionization efficiency, solubility, and dissociation behavior), or unexpected differences in concentration of some specific peptides from low abundance proteins (due to biological accumulation or loss), limit the accuracy of quantitative comparisons.

Analysis of all datasets leads to 57,192 ion assignments (hits). Of these, 37,842 correspond to unique peptide sequences. Assuming that these sequences arise from a protein that existed in plasma, this list leads to 9087 unique protein assignments. Many of the catalogued proteins have multiple peptide hits. 
Figure $^{\circ} 3^{\circ}$ provides $^{\circ}$ an $^{\circ}$ example $^{\circ}$ of $^{\circ}$ how $^{\circ}$ the $^{\circ}$ number $^{\circ}$ of peptide hits may vary over the list of proteins. For the apolipoprotein A-I sequence, analysis of all datasets leads to 930 hits of 39 different peptides. This corresponds to $\sim 88 \%$ of the total sequence of the protein. Only six short peptides and one longer peptide were
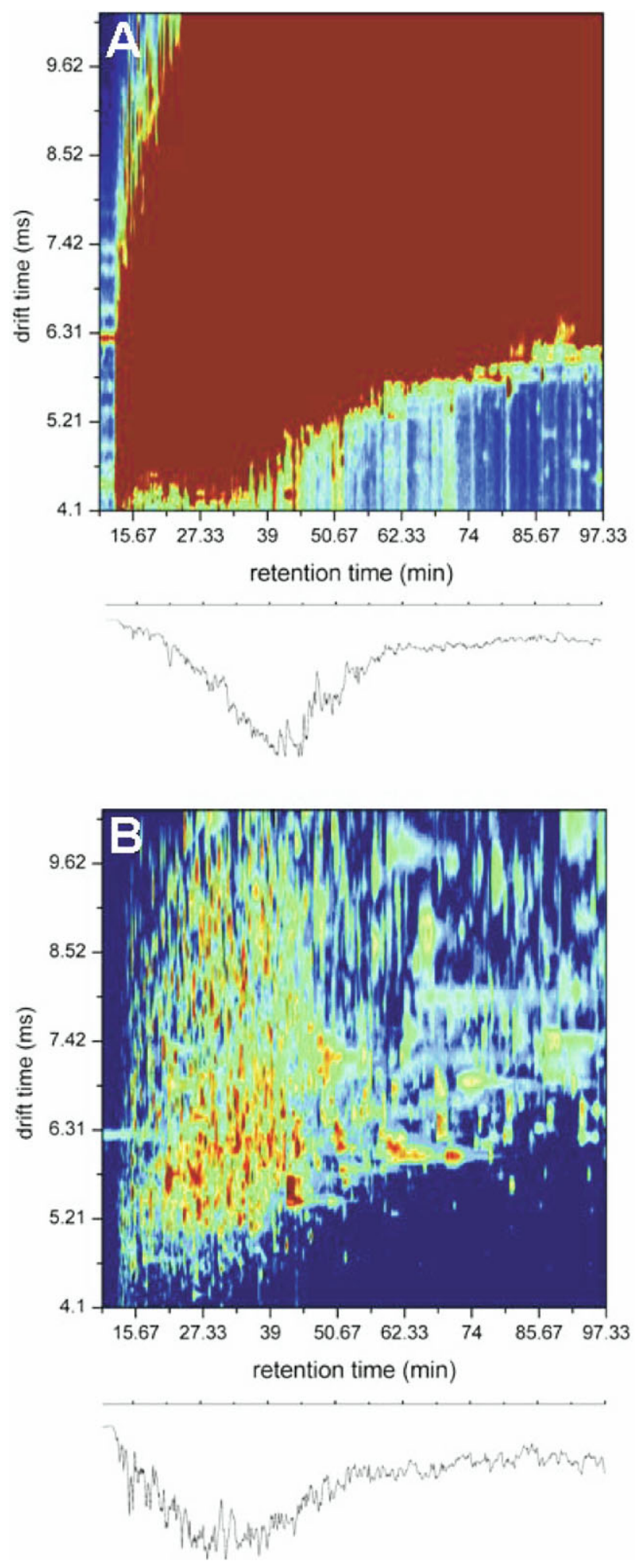

not included in the coverage: $M K, A K, A R, Q R$, LAAR, LNTQ, and AAVLTLAVLFLTGSQAR. Interestingly $\mathrm{MK}, \mathrm{AK}, \mathrm{AR}$, and $\mathrm{QR}$ are not unique and thus, although we have detected these peptides, it is not known whether or not they arise from apolipoprotein A-I. The LNTQ sequence is not a tryptic sequence and therefore was not included in our search algorithm. Additionally, none of these peptides (with the exception of the 17-residue peptide) would meet one of our search criteria (imposed after database assignment and used to reduce the number of false positives-that fragment ions must correspond to cleavage between at least five residues). The kallikrein and troponin I assignments are based on six and two hits, respectively. In these cases we find no evidence for large regions of the sequence. Because of this, assignments are far less robust (as discussed ${ }^{\circ}$ below).

Tables $^{\circ} 1^{\circ}$ and $^{\circ} 2^{\circ}$ provide $^{\circ} \mathrm{a}^{\circ}$ means ${ }^{\circ}$ of ${ }^{\circ}$ illustrating ${ }^{\circ}$ the structure of the overall map. Note that the tables that are shown are for example only. The complete maps are provided as Supplementary Information section in Tables S1 and S2, respectively (which can be found in the electronic ${ }^{\circ}$ version ${ }^{\circ} f^{\circ}$ this $^{\circ}$ article). ${ }^{\circ}$ Table $^{\circ} 1{ }^{\circ}$ is $^{\circ}$ an ${ }^{\circ}$ accumulation of all uniquely assigned peptides and their corresponding proteins. It includes the positions (in all dimensions of the analysis) and intensities of peaks, the homology scores used to make each assignment, the corresponding protein, and its accession number. In total Table S1 contains entries for 37,842 unique peptide ions. A useful way of understanding the information in Table S1 comes from the representation of their LC, IMS, ${ }^{\circ}$ and ${ }^{\circ} \mathrm{MS}^{\circ}$ positions $^{\circ}{ }^{\circ}{ }^{\circ}$ Shown $^{\circ}{ }^{\circ}{ }^{\circ}$ Figure $^{\circ} 4 .^{\circ}$ This $^{\circ}$ plot shows the positions of the 100,000 most intense features that appear from the triplicate analysis of Sample 1. Features associated with all eight of the SCX fractions are included. The arrows represent features that are associated with specific assignments for four proteins (the three described in Figure $3^{\circ}$ as ${ }^{\circ}$ well as transthyretin). In this case there are many more positions associated with the detection of apolipoprotein A-I than with detection of troponin. Although we have not analyzed the data in this fashion, knowledge of the positions of peaks will further corroborate assignments of the other

Figure 2. (a) Shows a 2D, $t_{R}\left(t_{D}\right)$ plot of the raw data (A) for a single SCX fraction (Sample 3). The plot is obtained by summing all TOF bins at each $t_{R}$ and $t_{D}$ value. Intensities are represented as a color map with the most intense level set at 150 counts. The representation indicates that individual 2D bins are saturated across a wide range of retention and drift times. (b) Shows the same data when plotted as a $2 \mathrm{D}, t_{R}\left(t_{D}\right)$ base-peak diagram. This plot is obtained by extracting the intensity value obtained for the most intense $\mathrm{m} / \mathrm{z}$ value in the MS measurement (extracted for every $t_{R}\left(t_{D}\right)$ position to create the contour plot). The traces below each contour plot show the ion chromatograms obtained by integrating all $t_{D}$ bins at each $t_{R}$ for the respective 2D plots. For more details about the generation of these datasets see text references and discussion therein. 


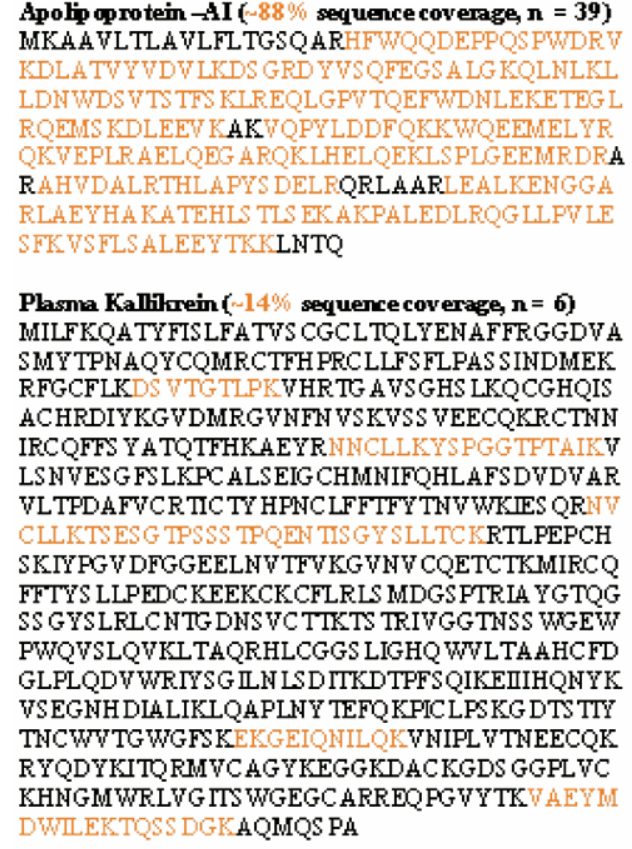

T roponin I ( $18 \%$ sequence coverage $\mathbf{n}=\mathbf{2}$ ) PEVERKPKITASRKLLLKSLMLAKAKEC WEQEHEER EAEKVRYLA ERIPTLQTRGLSLSALQDLCRELHAKVE VVDEERY DIEAKCLHWTREIKDLKLKVMDLRGKFKR PPLRRVRVSADAMLRALLGSKHKVS MDLRAHLKS V KKEDTEKERPVEW GDWRKWVEAMS GMEG RKKMFD AAKS PTSQ

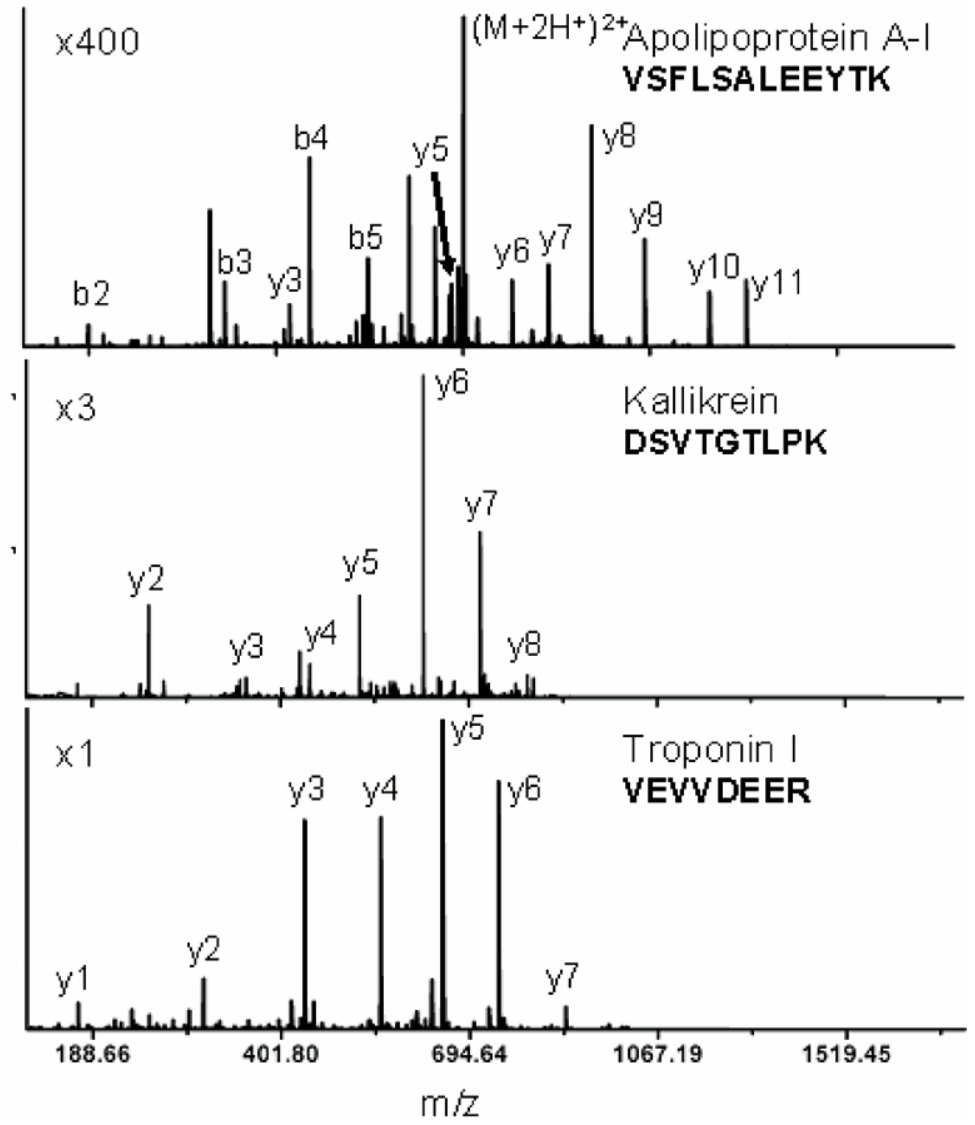

Figure 3. The plots on the right show fragmentation spectra of three identified peptides that have been identified based on database assignments (see text). These spectra are generated experimentally when the second field region of the split-field drift tube is modulated to high-field conditions sufficient to induce fragmentation. The low-field modulation data associated with measurement of the precursor ions (acquired in alternating fashion throughout the entire dataset) is not shown. The spectra that are shown are consistent with the VSFLASALEEYTK, DSVTGTLPK, and VEVVDEER sequences that are unique to the proteins apolipoprotein A-I, plasma kallikrein, and troponin I. The labels given to fragment ions in the spectra are generated by the database assignment and show a preponderance of y-type fragments (generally the observation for fragments generated at high-fields in these studies). The sequences to the left correspond to the total amino acid sequences of each of the respective proteins and those regions that are covered by assignments of peptides based on this approach are shown in red. Also indicated is number of unique peptide ions identified for each protein and the percentage of the sequence that has been identified by the analysis. See text for details. datasets. In addition, the accumulation of data in Table S1 provides valuable information for future work that would aim to predict SCX-retention times, LC-retention times, and mobilities based on sequences and charge states.

The $^{\circ}$ example $^{\circ}$ shown $^{\circ}$ as $^{\circ}$ Table $^{\circ} 2^{\circ}$ lists ${ }^{\circ} 20^{\circ}$ proteins ${ }^{\circ}$ that are identified from assignments made on data for all five samples. Those chosen here correspond to the most robust assignments in that they represent our top 20 in terms of cumulative hits. In addition to information about the number of hits, we also include the integrated ion intensities for the precursor ion peaks that were assigned (the complete list of proteins with the corresponding number of peptide hits and summed intensity values can be found in Table S1). The number of peptide ion assignments (hits) and the summed intensities are highly correlated. For example, a comparison of the number of peptide hits and integrated intensities for ${ }^{\circ}$ the ${ }^{\circ}$ extremes ${ }^{\circ}$ listed ${ }^{\circ}{ }^{\circ}{ }^{\circ}$ Table $^{\circ} 2^{\circ}$ shows $^{\circ}$ that ${ }^{\circ}$ there ${ }^{\circ}$ is ${ }^{\circ} a$ factor of $\sim$ seven times $(930 / 142)$ more hits, corresponding to $\sim$ nine times $\left(2.2 \times 10^{6} / 2.4 \times 10^{5}\right)$ more ion intensity for the first entry (apolipoprotein A-I) compared with the 20th entry $(\alpha$-1-acid glycoprotein 1 precursor). An additional impression about the number of times different proteins are identified based on this approach ${ }^{\circ} \mathrm{can}^{\circ} \mathrm{be}^{\circ}$ obtained $^{\circ} \mathrm{by}^{\circ} \mathrm{examining}^{\circ} \mathrm{Figure}^{\circ} 5$. $^{\circ}$ This analysis shows that 1362 proteins are assigned by at least 10 peptide hits. This number decays dramatically as the number of hits increases. For example, only 70 proteins are defined by more than 40 peptide hits.

As a final comment, we note that most of the peaks in these datasets do not lead to assignments (less than $0.1 \%$ of the precursor ion peaks are assigned using the present criteria). The low fraction of assignments 
Table 1. Peptide assignments from the integrated analysis of the human plasma samples ${ }^{\mathrm{a}}$

\begin{tabular}{|c|c|c|c|c|c|c|}
\hline Acc. $\#^{\mathrm{b}}$ & Protein name ${ }^{b}$ & Peptide sequence $^{c}$ & $z^{d}$ & $\mathrm{t}_{\mathrm{SCX}}\left\{\mathrm{t}_{\mathrm{R}}\left[\mathrm{t}_{\mathrm{D}}(m / z)\right]\right\}^{\mathrm{e}}$ & Intensity ${ }^{f}$ & Score ${ }^{g}$ \\
\hline \multirow[t]{5}{*}{ P02647 } & \multirow{5}{*}{$\begin{array}{l}\text { Apolipoprotein A-I } \\
\text { precursor (Apo-AI) } \\
\text { (ApoA-I) }\end{array}$} & DYVSQFE & 2 & $2.2\{44.04[6.79(70$ & $1.07 \mathrm{E}+05$ & 93 \\
\hline & & VSFLSALEEY & 3 & $5.2\{54.26[5.58$ & 1.22 & 91 \\
\hline & & LLDNWDSVTSTFSK & 2 & $3\{49.43[7.2(807.34)]\}$ & $1.72 \mathrm{E}+04$ & 89 \\
\hline & & VSFLSALEEYTK & 2 & $4.9\{63.28[7.03(694.15)]\}$ & $4.52 \mathrm{E}+05$ & 87 \\
\hline & & VSFLSALEEYTKK & 2 & $6\{52.71[5.69(758.44)]\}$ & $3.50 \mathrm{E}+03$ & 86 \\
\hline \multirow[t]{5}{*}{ P01024 } & \multirow{5}{*}{$\begin{array}{l}\text { Complement C3 } \\
\text { precursor [Contains: } \\
\text { C3a anaphylatoxin] }\end{array}$} & RIPIEDGSGEVVLSR & 3 & $4.7\{33.07[5.79(543.35)]\}$ & $1.52 \mathrm{E}+05$ & 116 \\
\hline & & SNLDEDIIAEENIVSR & 2 & $2.8\{40.26[7.19(909.18)]\}$ & $3.69 \mathrm{E}+03$ & 106 \\
\hline & & VPVAVOGEDTVOSLTOGDGVAK & 3 & $2\{39.16[6.89(733.77)]\}$ & $2.16 \mathrm{E}+04$ & 103 \\
\hline & & ENEGFTVTAEGK & 2 & $3.3\{24.18[6.58(641.47)]\}$ & $5.95 \mathrm{E}+04$ & 98 \\
\hline & & SEETKENEGFTVTAEGK & 3 & $4.5\{29.01[6.17(619.76)]\}$ & $1.61 \mathrm{E}+05$ & 96 \\
\hline \multirow[t]{5}{*}{ P02774 } & \multirow{5}{*}{$\begin{array}{l}\text { Vitamin D-binding } \\
\text { protein precursor } \\
\text { (DBP) (Group- } \\
\text { specific component) } \\
\text { (Gc-globulin) (VDB) }\end{array}$} & VPTADLEDVLPLAEDITNILSK & 3 & $3.7\{92.25[7.12(789.88)]\}$ & $2.02 \mathrm{E}+05$ & 112 \\
\hline & & LAOKVPTADLEDVLPLAEDITNILSK & 3 & $4.1\{85.13[7.76(936.6)]\}$ & $7.59 \mathrm{E}+04$ & 108 \\
\hline & & HQPQEFPTYVEPTNDEICEAFR & 3 & $7.5\{38.48[6.87(903.29)]\}$ & $9.51 \mathrm{E}+03$ & 105 \\
\hline & & KFPSGTFEOVSQLVK & 3 & $5.2\{40.65[5.86(565.81)]\}$ & $8.15 \mathrm{E}+04$ & 90 \\
\hline & & SCESNSPFPVHPGTAECCTK & 3 & $3.9\{23.45[6.48(755.97)]\}$ & $2.41 \mathrm{E}+04$ & 79 \\
\hline
\end{tabular}

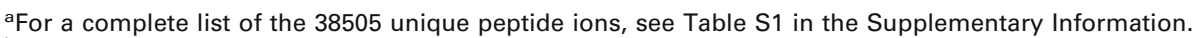

bProtein accession numbers and names have been obtained from the Swiss-Prot nonredundant human protein database (http://ca.expasy.org/). "Most frequently observed peptides for indicated proteins.

${ }^{\mathrm{d}}$ Charge states observed for indicated peptides yielding the highest Mascot ion scores.

${ }^{e}$ Average nested multidimensional retention and drift times as well as $\mathrm{m} / \mathrm{z}$ values indicated peptides [ $\left.\mathrm{t}_{\mathrm{Scx}}(\mathrm{fraction} \mathrm{number}), \mathrm{t}_{\mathrm{R}}(\mathrm{min}), \mathrm{t}_{\mathrm{D}}(\mathrm{ms}), \mathrm{m} / \mathrm{z}\right]$. fSummed precursor ion intensities obtained for each peptide assigned across the dataset.

gHighest Mascot ion score obtained for the indicated peptide.

may result from several factors: limitations in the quality of the CID data generated in the drift tube (a relatively new approach that has not been tested extensively); substantial overlap of fragments from multiple different precursor ions that complicates spectra; and the restriction of assignments to only tryptic fragments containing up to only one missed cleavage and no considerations of post-translational modifications.

\section{Considerations Associated with Detection of False Positives}

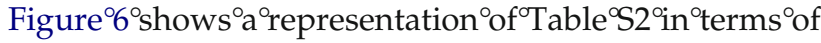
the total number of hits that are obtained for each of the 9087 entries associated with at least one hit. An issue that arises is which assignments should be trusted as components that are likely to be detectable with this type of approach. Examination of these data show that there is an apparent transition in the curve that occurs at about 60 - essentially the number of proteins that are assigned ${ }^{\circ}$ using ${ }^{\mathrm{T}}$ two-dimensional ${ }^{\circ} \mathrm{gels}^{\circ}[15],{ }^{\circ}{ }^{\circ}$ comprised ${ }^{\circ}$ of mostly the high-abundance classical plasma proteins [3]..$^{\circ}$ Our $^{\circ}$ expectation ${ }^{\circ}$ is $^{\circ}$ that ${ }^{\circ}$ the ${ }^{\circ}$ total $^{\circ}$ number ${ }^{\circ}$ of ${ }^{\circ}$ hits should be roughly proportional to the protein concentration and size (larger proteins will have more peptides that can be detected). Thus, the transition at around 60 proteins reflects the fact that the concentrations of many proteins fall just slightly below the detection limits of the earlier technologies.

Beyond this number, the issue of how many proteins are detectable in plasma requires that we understand the threshold for detection in more detail. Probabilitybased scoring algorithms are prone to making false assignments ${ }^{\circ}[40],{ }^{\circ}$ even $^{\circ}$ with $^{\circ}$ the ${ }^{\circ}$ additional ${ }^{\circ}$ assignment criteria that we described above. Therefore it is worthwhile to examine the false-positive rate in more detail. This is done by determining the rate of assignments that are made when a nonsensical protein database is used $\left[40,{ }^{\circ} 82-85\right] .{ }^{\circ}$ This $^{\circ}$ database ${ }^{\circ}$ was $^{\circ}{ }^{\circ}$ reated ${ }^{\circ}$ by $^{\circ}$ inverting ${ }^{\circ}$ all protein sequences in the Swiss-Prot nonredundant human database. Estimated false-positive rates range from $\sim 6 \%{ }^{\circ}$ to ${ }^{\circ} 10 \%{ }^{\circ}$ from ${ }^{\circ}$ replicate ${ }^{\circ}$ analyses ${ }^{\circ}[9]$.

Figure ${ }^{\circ} 6^{\circ}$ shows $^{\circ} a^{\circ}$ plot $^{\circ}$ of ${ }^{\circ}$ the $e^{\circ}$ number ${ }^{\circ} f^{\circ}{ }^{\circ}$ times ${ }^{\circ}$ that ${ }^{\circ} a$ protein would be randomly assigned [using a 10\% false-positive rate (the upper end of the range) and three times this value (30\%)]. From this analysis we observe that a substantial fraction of those proteins that are assigned based on only a few hits are likely to be random assignments (Table S2). Briefly, peptide ion hits (equal to the number of false positives) are removed randomly from the total protein list. Upon randomly hitting a protein assignment a number of times equal to the number of peptide ion hits, it is removed from the high-confidence protein list. Inspection of the remaining proteins allows one to determine the threshold hit level for which none of the proteins was removed from the list. For example, $45 \%$ to $88 \%$ of assignments based on a single peptide hit are random (using the $10 \%$ and $30 \%$ false-positive rate limits, respectively). This number drops to $12 \%$ to $64 \%$ of the assignments if two hits are used. A random assignment rate of fewer than one in 20 is found at the $30 \%$ false positive rate when at least six hits are used to identify a single protein (note that no false-positives are predicted at six hits when our $10 \%$ false positive rate is used). From the threshold value of six, we determine that 2928 of these identifications are high-confidence assignments. We anticipate that more low-abundance species will become high-confidence assignments as more experiments are conducted. 


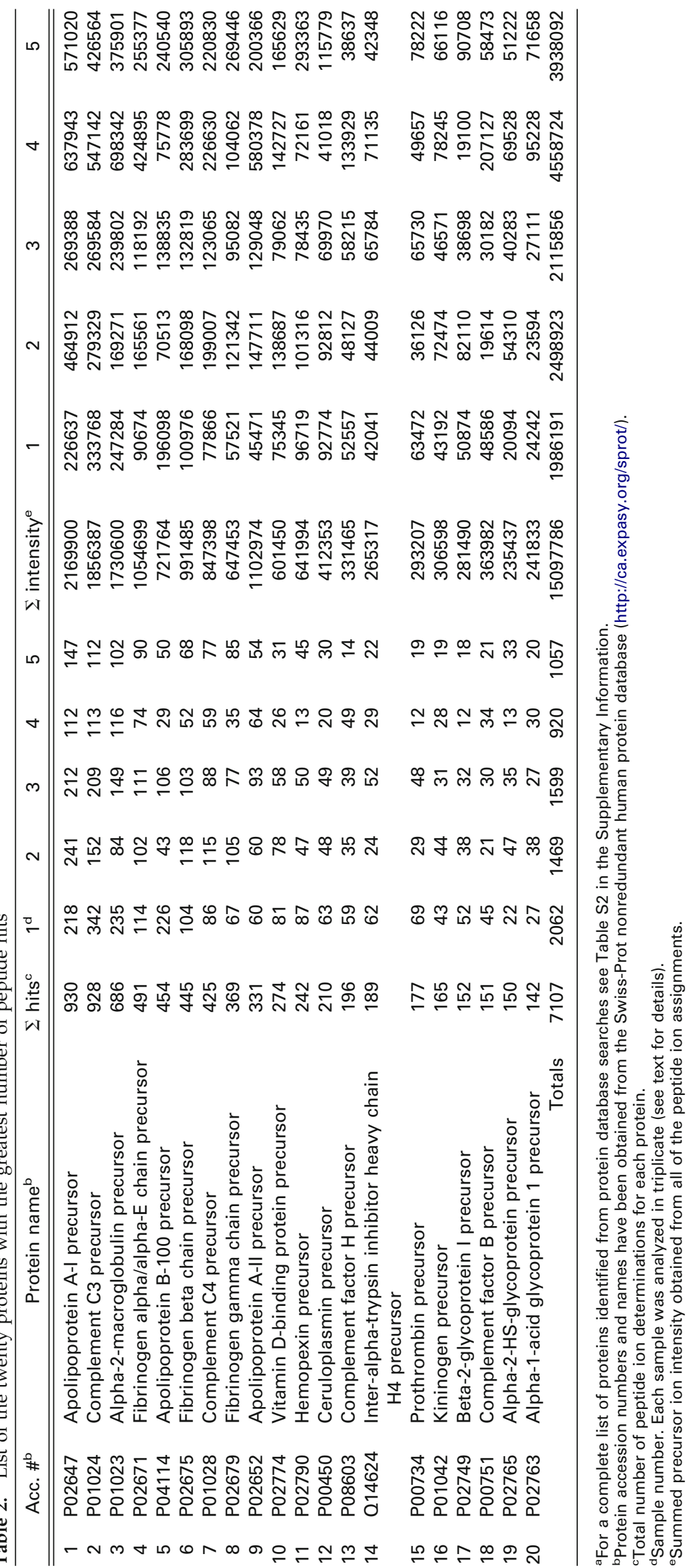




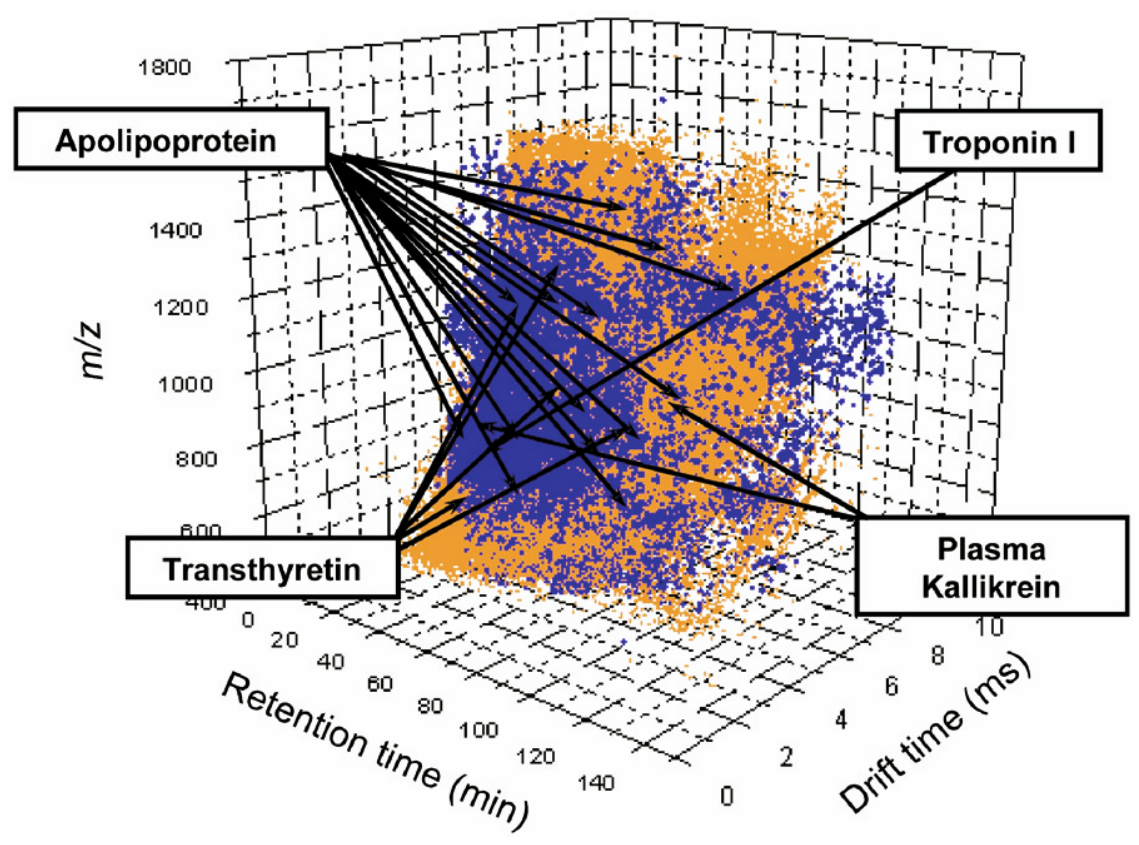

\begin{abstract}
Figure 4. A 3D dot plot representation of the positions of peaks (in the retention time, drift time, and $\mathrm{m} / z$ dimensions) that are obtained from the $1 \times 10^{5}$ most intense features (orange) observed during the triplicate LC-IMS-MS analyses of all SCX fractions associated with Sample 1. Superimposed on the plot are the positions for $>10,000$ features that have been assigned to peptides (blue). The arrows indicate some of the precursor ion positions of peptides identified for the four proteins labeled. This representation is intended to provide the reader with the impression that the possible existence of an abundant protein in plasma (such as apolipoprotein A-I) could be tested at many positions in the map and therefore upon comparison there should be little ambiguity regarding its detection; whereas, a low-abundance protein (such as troponin I) may be represented at only a single position, leading to significant uncertainty about its detection. See text for discussion.
\end{abstract}

As a final note, in a preliminary set of experiments using a substantially longer drift tube $(\sim 3 \mathrm{~m})$ that is operated under conditions that provide a factor of $\sim$ three to four times improvement in peak capacity (in the ${ }^{\circ}$ drift $^{\circ}$ time $^{\circ}$ dimension $^{\circ}[9]^{\circ}$, we $^{\circ}$ find $^{\circ}$ substantial ${ }^{\circ}$ increases in the MASCOT scores for peptides associated with abundant proteins (in direct comparisons of the same sample analyzed on different instruments). This result is consistent with the idea that simultaneous elution of multiple components interferes with assigning features. At this stage, comparisons can only be made for abundant species that are already known to be present in plasma. We are currently in the process of improving the sensitivity of this instrument so that this method can also be used to confirm (or dispute) the assignments we have made for lower abundance components.

\section{Features of the Plasma Proteome Map}

It is instructive to consider the types of proteins observed in the high-confidence list. Anderson, Smith, and their collaborators have previously assessed the content of plasma based on considerations of Gene Ontology $^{\circ}(\mathrm{GO})^{\circ}\left[15,{ }^{\circ} 21,{ }^{\circ} 39\right] .^{\circ}$ In $^{\circ}$ general $^{\circ}$ terms, ${ }^{\circ}$ this provides a representation of where in the cell different proteins ${ }^{\circ}$ are ${ }^{\circ}$ distributed. ${ }^{\circ}$ Figure ${ }^{\circ}{ }^{\circ}$ shows ${ }^{\circ}$ the ${ }^{\circ}$ percentage of each GO component in the entire Swiss-Prot database as well as the percentage of each component in the current plasma map. The percentages are significantly different for several key components (e.g., the extracellular, cytoplasmic, and nuclear components). The dif-

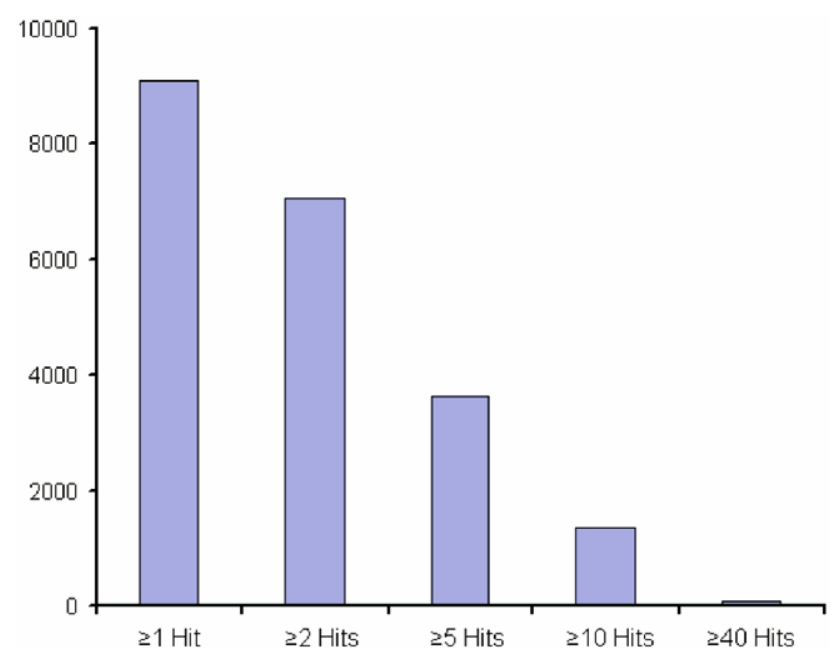

Figure 5. Bar graph showing the total number of proteins as a function of observed peptide hits per protein. The numbers for all assigned proteins are given in the Supplementary Information (Table S2). 

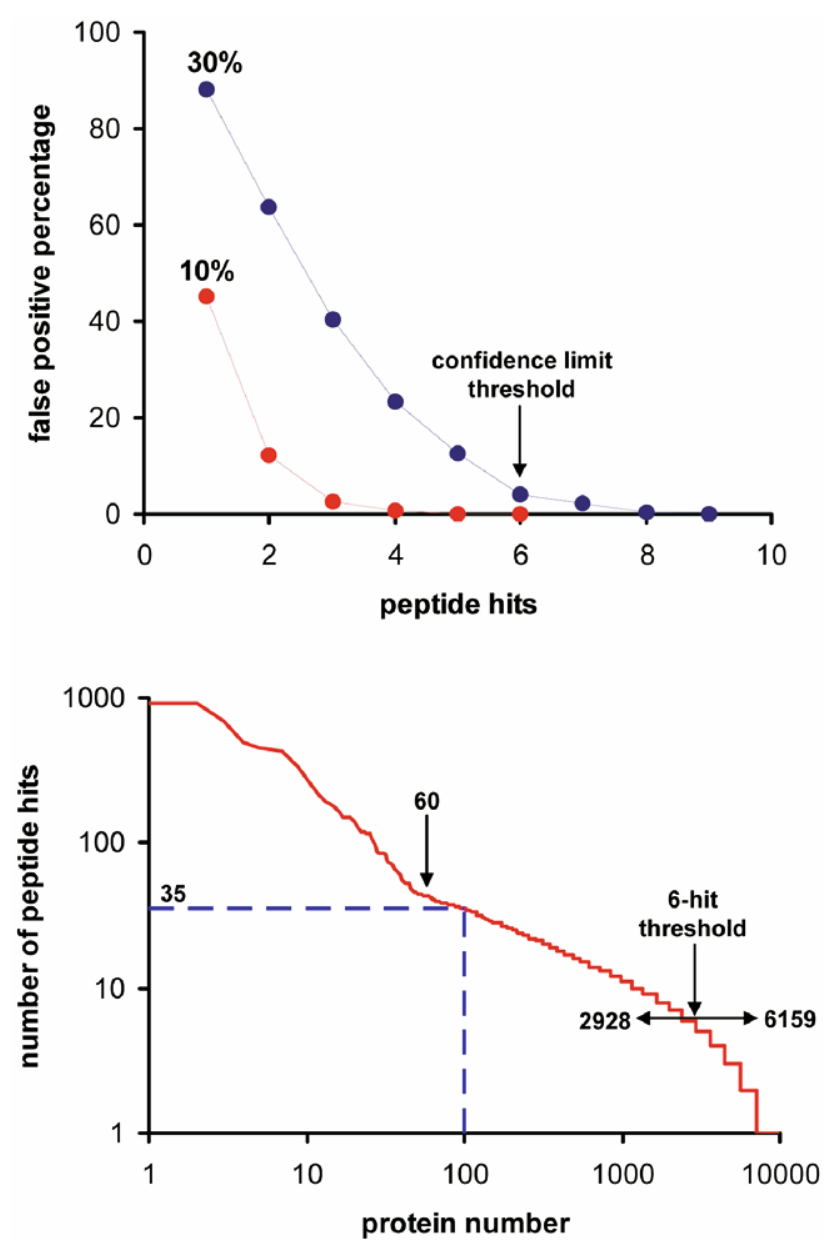

Figure 6. The top graph shows the percentage of false positive assignments for each peptide hit level from the random peptide hit removal analysis (see text for description) using the $10 \%$ (red) and $30 \%$ (blue) false positive rate estimates. Note that the $30 \%$ limit is a factor of three times greater than the upper limit of the $(6 \%$ to $10 \%)$ range established in the false-positive rate estimate and is included to provide a feeling about an extreme limit (see text for discussion). The arrow shows the peptide hit threshold for which no proteins were randomly removed at six hits and above (at a $10 \%$ false positive rate) and less than 1 in 20 protein assignments is considered a false positive (from the 30\% trace). The bottom graph shows a log-log plot of the total number of peptide hits for each identified protein (Table S1, Supplementary Information). The dashed line shows the peptide hit level for the 100th protein (35 hits). The 6-hit threshold (obtained from the top plot) is also shown with an arrow which indicates the cutoff between the 2928 proteins that are defined as high-confidence assignments (to the left of the threshold) and the 6159 lowconfidence assignments (to the right of the threshold). An additional arrow at protein number 60 indicates the number of proteins that were detected using 2D gel techniques, most of which are classical plasma proteins (see text). The change in slope near this value reflects a transition in concentrations between these more abundant components (mostly classical plasma proteins) and those that arise from tissue leakage.

ferences further corroborate the notion that the map is not composed of random assignments. If it were, the percentages of each GO component in the plasma map would more closely mimic those in the protein database. Perhaps a better comparison is to look at the protein makeup by including a weighting factor for each protein based on the number of peptide ion hits. Figure ${ }^{\circ} 7 c^{\circ}$ shows ${ }^{\circ}$ the ${ }^{\circ}$ change ${ }^{\circ}{ }^{\circ}{ }^{\circ} \mathrm{GO}^{\circ}$ component $^{\circ}$ percentages when the protein list is weighted by the number of peptide hits used to represent it. A noticeable increase in the percentage $(13 \%$ to $28 \%)$ of the extracellular component is observed with a decrease in the overall percentage (39\% to $28 \%$ ) of the membrane component. This is consistent with the greater number of observations of classical plasma proteins.
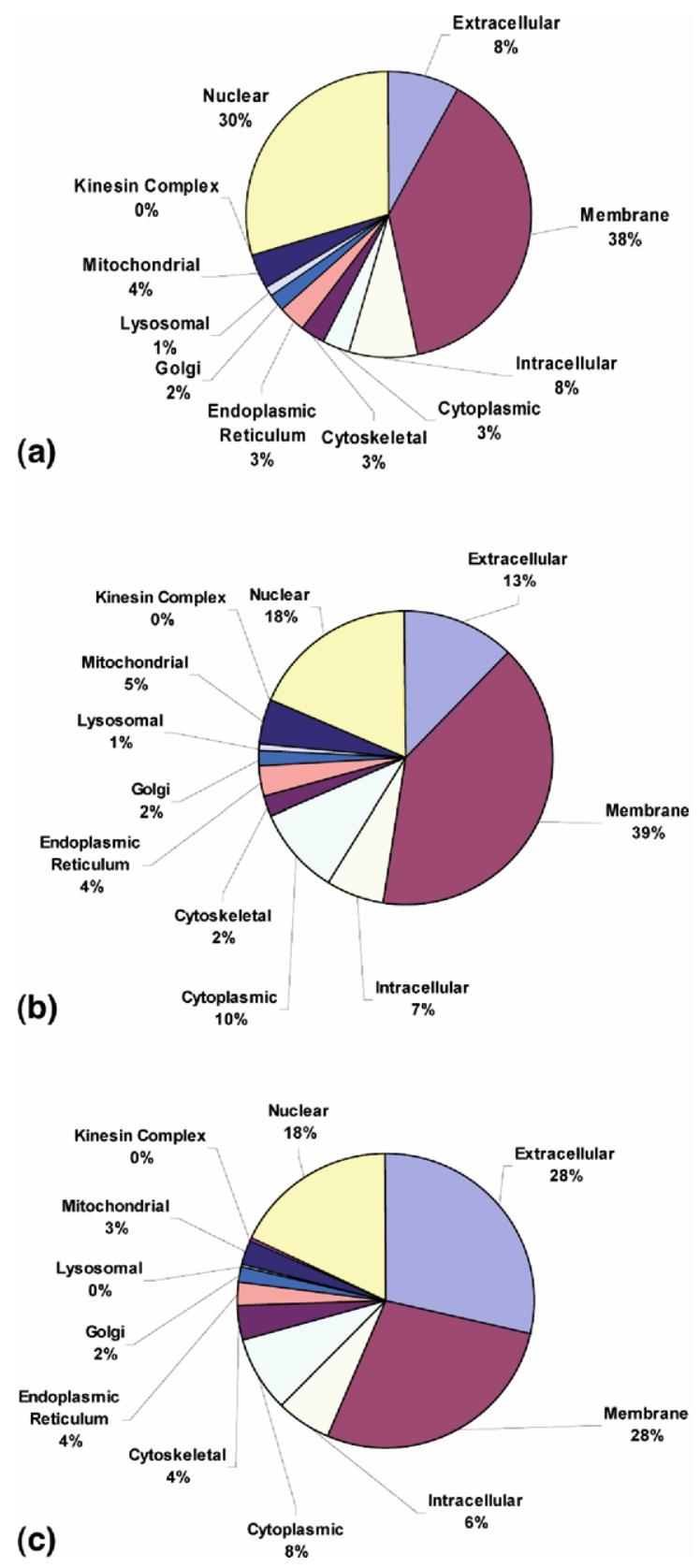

Figure 7. Major gene ontology (GO) component percentages for the entire human proteome (a), the plasma proteome generated from IMS-MS experiments (b), as well as the proteome map weighted by the number of protein hits (c). See text for discussion. 


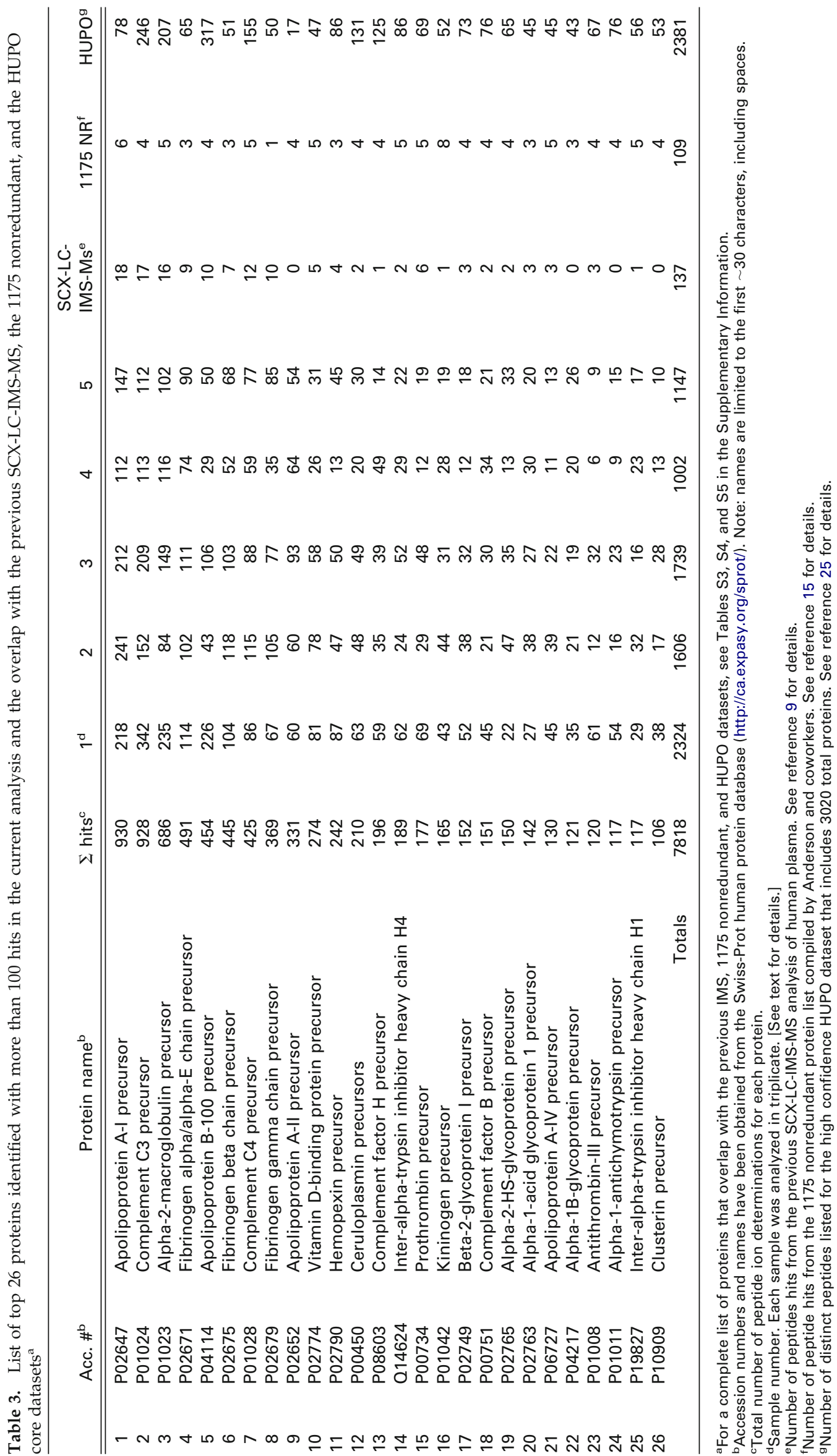




\section{Comparison of this Map with Others}

As a check of consistency, it is useful to compare the high-confidence list of proteins with other maps of plasma. We arbitrarily began by comparing 26 proteins that we observed with at least 100 hits to our previous SCX-LC-IMS-MS ${ }^{\circ}$ analysis in ${ }^{\circ}$ Table 30 [9]. ${ }^{\circ}$ Although ${ }^{\circ}$ there is substantial variability in the number of peptide hits, most (22) of the 26 proteins are detected in the previous study. A comparison to our complete list observed previously shows that 252 of the 438 proteins reported previously are reported as high-confidence assignments in the current studies. The overlap can be found in the Supplementary Information (Table S3).

A second comparison involves the 1175 nonredundant $^{\circ}{ }^{\circ}$ ataset ${ }^{\circ}$ compiled $^{\circ} y^{\circ}$ Anderson ${ }^{\circ}{ }^{\circ}{ }^{\circ}{ }^{\circ}$ coworkers $[15]$. Our top 26 proteins all overlap with the Anderson list (Table ${ }^{\circ}$ ).$^{\circ}$ Their $^{\circ}$ analysis ${ }^{\circ}$ determined ${ }^{\circ}$ that ${ }^{\circ}$ only ${ }^{\circ} 46^{\circ}$ proteins were observed from all sources. We note that all 46 of those proteins are observed as high-confidence assignments in our present study. Interestingly, they are all found in our top 100 proteins. A more detailed comparison of the 2928 high-confidence protein assignments with the 1175 protein list shows that 321 proteins are found in both (see Table S4).

Finally, we have compared some of our maps to some data reported by the plasma proteome project (PPP). ${ }^{\circ}$ In $^{\circ}$ the ${ }^{\circ}$ case $^{\circ}$ of ${ }^{\circ}$ the ${ }^{\circ} 26^{\circ}$ proteins ${ }^{\circ}$ in ${ }^{\circ}$ Table $^{\circ} 3^{\circ}$, all ${ }^{\circ}$ are also reported in the PPP dataset. It is more difficult to compare with the complete PPP database because the system of protein accession numbers is from multiple, independently curated databases. Comparison by name and accession number (a by-hand comparison) of our top 300 proteins with the 3020 core dataset provided by HUPO shows that 185 are found in both datasets (provided as Table S5 in the Supplementary Information).

\section{Considerations of Dynamic Range}

Commercial MS instruments have a dynamic range of $\sim 10^{2}-10^{5^{\circ}}\left[86^{\circ}-90\right]$. The ${ }^{\circ}$ inclusion ${ }^{\circ}$ of $^{\circ}{ }^{\circ}{ }^{\circ} M^{\circ}{ }^{\circ}$ dimension ${ }^{\circ}$ is expected to improve this due to the removal of chemical noise ${ }^{\circ}[8] .{ }^{\circ}$ From $^{\circ}$ assignments ${ }^{\circ}$ that ${ }^{\circ}{ }^{\circ}$ all ${ }^{\circ}$ at ${ }^{\circ}$ the ${ }^{\circ}$ threshold associated with high-confidence assignments, we can assess the expected dynamic range of this system. As examples, troponin I, prostatic acid phosphatase, and thyroxine-binding globulin protein each were observed with five peptide hits (just below the high-confidence threshold). The concentrations of these proteins are 1.0, $1.7,{ }^{\circ}$ and $^{\circ} 14.1^{\circ}$ ng- $\mathrm{mL}^{-1},{ }^{\circ}$ respectively ${ }^{\circ}[90]^{\circ} .^{\circ}$ The ${ }^{\circ}$ proteins thyroglobulin, tissue-type plasminogen activator, and plasma kallikrein are observed 21, eight, and nine times, respectively, in the plasma map. These proteins have nominal plasma concentrations of 19.0, 5.5, and 55.0 ng- $\mathrm{mL}^{-1}$, respectively. This analysis suggests that for most species we might expect an estimated lower limit for identification in the low ng- $\mathrm{mL}^{-1}$ range; this would suggest an experimental dynamic range of $10^{5}$ to $10^{6}$.
Within the high-confidence dataset, a single interleukin (reported as IL-16 precursor in Table S1, but only represented with hits in the body of the protein) was observed (15 peptide ion hits across seven unique regions of sequence). Based on our confidence analysis, we expect this to be a reproducible signal with this approach. However, clearly some additional caution should be taken in considering this assignment (as with any other assignment for a protein that is known to exist in extremely low abundances). Assuming an IL-16 protein concentration of $\sim 10 \mathrm{pg}-\mathrm{mL}^{-1}$ (within plasma, and no sample loss during workup), would require detection of $\sim 5 \mathrm{pg}$ or $\sim 75$ attomol. This approaches the ultimate measured detection limit for this instrumentation ${ }^{\circ}[54] .^{\circ} \mathrm{We}{ }^{\circ}$ include ${ }^{\circ}$ the ${ }^{\circ}$ result $^{\circ}$ in ${ }^{\circ}$ our ${ }^{\circ}$ high-confidence list because it meets the imposed criteria. However, we urge the users of this map to approach this and other assignments for species that are known to exist at very low abundances cautiously.

\section{Summary and Conclusions}

A multidimensional SCX-LC-IMS-MS experiment combined with a database assignment approach has been used to generate a plasma proteome map. Triplicate analyses of plasma from five healthy people results in assignment of 9087 proteins of which 2928 are expected to be reproducibly detected with this experimental approach. The map contains information about protein accession numbers and names, peptides used for assignments, as well as peak positions within the multidimensional space and intensities. Comparison of these assignments with those found in other maps suggests good agreement for the most abundant components. There is reasonable agreement about the first several hundred proteins in our map with other datasets. Beyond this level, many components in the map developed here appear to be unique to our approach; additionally, this analysis does not assign many features that are included in other summaries.

\section{Acknowledgments}

The authors are especially grateful for the careful and thoughtful reviews of prior related papers involving fundamental ion structure and instrumentation; this feedback has often clarified our understanding, and without it we would not have been encouraged to develop this map. The authors acknowledge C. Ray Sporleder, Frank Gao, Randy Arnold, and Meera Krishnan for their contributions to data analysis. This work was supported by grants from the National Institute of Health (R01-AG-024547), the Analytical Node of the METACyt Initiative, funded by the Lilly Endowment, and the Indiana 21st Century fund.

\section{References}

1. Wasinger, V. C.; Cordwell, S. J.; Cerpa-Poljak, A.; Yan, J. X.; Gooley, A. A.; Wilkins, M. R.; Duncan, M. W.; Harris, R.; Williams, K. L.; Humphery-Smith, I. Progress with Gene-Product Mapping of the Mollicutes: Mycoplasma Genitalium. Electrophoresis 1995, 16, 1090-1094.

2. Hancock, W. S.; Apffel, A. J.; Chakel, J. A.; Hahnenberger, K. C.; Choudhary, G.; Traina, J.; Pungor, E. Integrated Genomic/Proteomic 
Analysis. Anal. Chem. 1999, 71, 742A-748A. Schweitzer, B.; Kingsmore, S. F. Measuring Proteins on Microarrays. Curr. Opin. Biotech. 2002, 13, 14-19. Figeys, D. Proteomics in 2002: A Year of Technical Development and Wide-Ranging Applications. Anal. Chem. 2003, 75, 2891-2905. Romijn, E. P.; Krijgsveld, J.; Heck, A. J. R. Recent Liquid Chromatographic-(Tandem) Mass Spectrometric Applications in Proteomics. J. Chromatogr. A 2003, 1000, 589-608. Aebersold, R. Mann, M. Mass Spectrometry-Based Proteomics. Nature 2003, 422, 198-207. Page, J. S.; Masselon, C. D.; Smith, R. D. FTICR Mass Spectrometry for Qualitative and Quantitative Bioanalyses. Curr. Opin. Biotech. 2004, 15, 3-11. Anderson, L. Candidate-Based Proteomics in the Search for Biomarkers of Cardiovascular Disease. J. Physiol. (London) 2005, 563, 23-60.

3. Anderson, N. L.; Anderson, N. G. The Human Plasma Proteome: History, Character, and Diagnostic Prospects. Mol. Cell. Proteom. 2002, 1, $845-867$.

4. Liu, X.; Plasencia, M.; Ragg, S.; Valentine, S. J.; Clemmer, D. E. Development of High-Throughput Dispersive LC-Ion Mobility-TOFMS Techniques for Analyzing the Human Plasma Proteome. Brief Funct Genomic Proteomic 2004, 3, 177-186.

5. ${ }^{\circ}$ http://www.expasy.uniprot.org/database/knowledgebase.shtml.

6. Tirumalai, R. S.; Chan, K. C.; Prieto, D. A.; Issaq, H. J.; Conrads, T. P.; Veenstra, T. D. Characterization of the Low Molecular Weight Human Serum Proteome. Mol. Cell. Proteom. 2003, 2, 1096-1103.

7. Putnam, F. W., Ed. The Plasma Proteins: Structure, Function and Genetic Control; Academic Press: New York, 1975.

8. Counterman, A. E.; Hilderbrand, A. E.; Srebalus Barnes, C. A.; Clemmer, D. E. Formation of Peptide Aggregates during ESI: Size, Charge, Composition, and Contributions to Noise. J. Am. Soc. Mass Spectrom. 2001, 12, 1020-1035

9. Valentine, S. J.; Plasencia, M. D.; Liu, X.; Krishnan, M.; Naylor, S.; Udseth, H. R.; Smith, R. D.; Clemmer, D. E. Toward Plasma Proteome Profiling with Ion Mobility-Mass Spectrometry. J. Proteome Res. 2006, 5, 2977-2984.

10. Anderson, N. L.; Anderson, N. G. A Two-Dimensional Gel Database of Human Plasma Proteins. Electrophoresis 1991, 12, 883-906.

11. Ueno, I.; Sakai, T.; Yamaoka, M.; Yoshida, R.; Tsugita, A. Analysis of Blood Plasma Proteins in Patients with Alzheimer's Disease by TwoDimensional Electrophoresis, Sequence Homology, and Immunodetection. Electrophoresis 2000, 21, 1832-1845.

12. Pieper, R.; Gatlin, C. L.; Makusky, A. J.; Russo, P. S.; Schatz, C. R.; Miller, S. S.; Su, Q.; McGrath, A. M.; Estock, M. A.; Parmar, P. P.; Zhao, M. Huang, S. T.; Zhou, J.; Wang, F.; Esquer-Blasco, R.; Anderson, N. L.; Taylor, J.; Steiner, S. The Human Serum Proteome: Display of Nearly 3700 Chromatographically Separated Protein Spots on Two-Dimensional Electrophoresis Gels and Identification of 325 Distinct Proteins. Proteomics 2003, 3, 1345-1364.

13. Anderson, L.; Anderson, N. G. High Resolution Two-Dimensional Electrophoresis of Human Plasma Proteins. Proc. Natl. Acad. Sci. U.S.A 1977, 74, 5421-5425

14. Dunn, M. J. Two-Dimensional Gel Electrophoresis of Proteins. J. Chromatogr. 1987, 418, 145-185.

15. Anderson, N. L.; Polanski, M.; Pieper, R.; Gatlin, T.; Tirumalai, R. S.; Conrads, T. P.; Veenstra, T. D.; Adkins, J. N.; Pounds, J. G.; Fagan, R.; Lobley, A. The Human Plasma Proteome: A Nonredundant List Developed by Combination of Four Separate Sources. Mol. Cell. Proteom. 2004, 3, 311-326.

16. Wolters, D. A.; Washburn, M. P.; Yates, J. R. An Automated Multidimensional Protein Identification Technology for Shotgun Proteomics. Anal. Chem. 2001, 73, 5683-5690

17. Washburn, M. P.; Wolters, D.; Yates, J. R. Large-Scale Analysis of the Yeast Proteome by Multidimensional Protein Identification Technology. Nat. Biotechnol. 2001, 19, 242-247.

18. Peng, J.; Elias, J. E.; Thoreen, C. C.; Licklider, L. J.; Gygi, S. P. Evaluation of Multidimensional Chromatography Coupled with Tandem Mass Spectrometry (LC/LC-MS/MS) for Large-Scale Protein Analysis: The Yeast Proteome. J. Proteome Res. 2003, 2, 43-50.

19. Adkins, J. N.; Varnum, S. M.; Auberry, K. J.; Moore, R. J.; Angell, N. H.; Smith, R. D.; Springer, D. L.; Pounds, J. G. Toward a Human Blood Serum Proteome: Analysis by Multidimensional Separation Coupled with Mass Spectrometry. Mol. Cell. Proteom. 2002, 1, 947-955.

20. Wu, S. L.; Choudhary, G.; Ramstrom, M.; Bergquist, J.; Hancock, W. S. Evaluation of Shotgun Sequencing for Proteomic Analysis of Human Plasma Using HPLC Coupled with either Ion Trap or Fourier Transform Mass Spectrometry. J. Proteome Res. 2003, 2, 383-393.

21. Shen, Y.; Jacobs, J. M.; Camp, D. G. II, Fang, R.; Moore, R. J.; Smith, R. D.; Xiao, W.; Davis, R. W.; Tompkins, R. G. Ultra-High-Efficiency Strong Cation Exchange LC/RPLC/MS/MS for High Dynamic Range Characterization of the Human Plasma Proteome. Anal. Chem. 2004, 76, 1134-1144.

22. Zhou, M.; Lucas, D. A.; Chan, K. C.; Issaq, H. J.; Petricoin, E. F.; Liotta, L. A.; Veenstra, T. D.; Conrads, T. R. An Investigation into the Human Serum "Interactome". Electrophoresis 2004, 25, 1289-1298.

23. Rose, K.; Bougueleret, L.; Baussant, T.; Böhm, G.; Botti, P; Colinge, J.; Cusin, I.; Gaertner, H.; Gleizes, A.; Heller, M.; Jimenez, S.; Johnson, A.; Kussmann, M.; Menin, L.; Menzel, C.; Ranno, F.; Rodriguez-Tomé, P.; Rogers, J.; Saudrais, C.; Villain, M.; Wetmore, D.; Bairoch, A.; Hochstrasser, D. Industrial-Scale Proteomics: From Liters of Plasma to Chemically Synthesized Proteins. Proteomics 2004, 4, 2125-2150.
24. Proteomics 2005, 13 (entire issue). Plasma Proteome Project (PPP) collaboration sponsored by the Human Proteome Organization (HUPO), Proteomics.

25. Omenn, G. S.; States, D. J.; Adamski, M.; Blackwell, T. W.; Menon, R.; Hermjakob, H.; Apweiler, R.; Haab, B. B.; Simpson, R. J.; Eddes, J. S.; Kapp, E. A.; Moritz, R. L.; Chan, D. W.; Rai, A. J.; Admon, A.; Aebersold, R.; Eng, J.; Hancock, W. S.; Hefta, S. A.; Meyer, H.; Paik, Y.; Yoo, J.; Ping, P.; Pounds, J.; Adkins, J.; Qian, X.; Wang, R.; Wasinger, V.; Wu, C. Y.; Zhao, X.; Zeng, R.; Archakov, A.; Tsugita, A.; Beer, I.; Pandey, A.; Pisano, M.; Andrews, P.; Tammen, H.; Speicher, D. W.; Hanash, S. M. Overview of the HUPO Plasma Proteome Project: Results from the Pilot Phase with 35 Collaborating Laboratories and Multiple Analytical Groups, Generating a Core Dataset of 3020 Proteins and a PubliclyAvailable Database. Proteomics 2005, 5, 3226-3245.

26. Chan, K. C.; Lucas, D. A.; Hise, D.; Schaefer, C. F.; Xiao, Z.; Janini,. George, M.; Buetow, K. H.; Issaq, H. J.; Veenstra, T. D.; Conrads, T. P. Analysis of the Human Serum Proteome. Clin. Proteom. 2004, 1, 101-226.

27. Jiang, L.; He, L.; Fountoulakis, M. Comparison of Protein Precipitation Methods for Sample Preparation Prior to Proteomic Analysis. J. Chromatogr. A 2004, 1023, 317-320.

28. Hsieh, S. Y.; Chen, R. K.; Pan, Y. H.; Lee, H. L. Systematical Evaluation of the Effects of Sample Collection Procedures on Low-MolecularWeight Serum/Plasma Proteome Profiling. Proteomics 2006, 6, 3189 3198 .

29. Liu, T.; Qian, W.-J ; Mottaz, H. M.; Gritsenko, M. A.; Norbeck, A. D. Moore, R. J.; Purvine, S. O.; Camp, D. G. II; Smith, R. D. Evaluation of Multiprotein Immunoaffinity Subtraction for Plasma Proteomics and Candidate Biomarker Discovery Using Mass Spectrometry. Mol. Cell. Proteom. 2006, 5, 2167-2174.

30. Banks, R. E.; Stanley, A. J.; Cairns, D. A.; Barrett, J. H.; Clarke, P. Thompson, D.; Selby, P. J. Influences of Blood Sample Processing on Low-Molecular-Weight Proteome Identified by Surface-Enhanced Laser Desorption/Ionization Mass Spectrometry. Clin. Chem. 2005, 51, 16371649.

31. Stone, E.; Gillig, K. J.; Ruotolo, B.; Fuhrer, K.; Gonin, M.; Schultz, A.; Russell, D. H. Surface-Induced Dissociation on a MALDI-Ion MobilityOrthogonal Time-of-Flight Mass Spectrometer: Sequencing Peptides from an "In-Solution" Protein Digest. Anal. Chem. 2001, 73, 2233-2238.

32. Wysocki, V. H.; Resing, K. A.; Zhang, Q. F.; Cheng, G. L. Mass Spectrometry of Peptides and Proteins. Methods 2005, 35, 211-222.

33. Mikesh, L. M.; Ueberheide, B.; Chi, A.; Coon, J. J.; Syka, J. E.; Shabanowitz, J.; Hunt, D. F. The Utility of ETD Mass Spectrometry in Proteomic Analysis. Biochim. Biophys. Acta 2006, 1764, 1811-1822.

34. Dodds, E. D.; Hagerman, P. J.; Lebrilla, C. B. Fragmentation of Singly Protonated Peptides via a Combination of Infrared and Collisional Activation. Anal. Chem. 2006, 78, 8506-8511.

35. Zubarev, R. Protein Primary Structure Using Orthogonal Fragmentation Techniques in Fourier Transform Mass Spectrometry. Expert. Rev. Proteom. 2006, 3, 251-261.

36. Bakhtiar, R.; Guan, Z. Q. Electron Capture Dissociation Mass Spectrometry in Characterization of Peptides and Proteins. Biotechnol. Lett. 2006, 28, 1047-1059.

37. Fernandez, F. M.; Wysocki, V. H.; Futrell, J. H.; Laskin, J. Protein Identification via Surface-Induced Dissociation in an FT-ICR Mass Spectrometer and a Patchwork Sequencing Approach. J. Am. Soc. Mass Spectrom. 2006, 17, 700-709.

38. Riter, L. S.; Gooding, K. M.; Hodge, B. D.; Julian, R. K. Comparison of the Paul Ion Trap to the Linear Ion Trap for Use in Global Proteomics. Proteomics 2006, 6, 1735-1740.

39. Jacobs, J. M.; Adkins, J. N.; Qian, W. J.; Shen, Y.; Camp, D. G., II; Smith, R. D. Utilizing Human Blood Plasma for Proteomic Biomarker Discovery. J. Proteome Res. 2005, 4, 1073-1085.

40. Cargile, B. J.; Bundy, J. L.; Stephenson, J. L., Jr. Potential for False Positive Identifications from Large Databases through Tandem Mass Spectrometry. J. Proteome Res. 2004, 3, 1082-1085.

41. Kapp, E. A.; Schutz, F.; Connolly, L. M.; Chakel, J. A.; Meza, J. E.; Miller, C. A.; Fenyo, D.; Eng, J. K.; Adkins, J. N.; Omenn, G. S.; Simpson, R. J. An Evaluation, Comparison, and Accurate Benchmarking of Several Publicly Available MS/MS Search Algorithms: Sensitivity and Specificity Analysis. Proteomics 2005, 5, 3475-3490.

42. States, D. J.; Omenn, G. S.; Blackwell, T. W.; Fermin, D.; Eng, J.; Speicher, D. W.; Hanash, S. M. Challenges in Deriving High-Confidence Protein Identifications from Data Gathered by a HUPO Plasma Proteome Collaborative Study. Nat. Biotechnol. 2006, 24, 333-338.

43. St. Louis, R. H.; Hill, H. H. Ion Mobility Spectrometry in Analytical Chemistry. CRC Crit. Rev. Anal. Chem. 1990, 21, 321-355.

44. Clemmer, D. E.; Hudgins, R. R.; Jarrold, M. F. Naked Protein Conformations: Cytochrome $c$ in the Gas Phase. J. Am. Chem. Soc. 1995, 117 10141-10142

45. von Helden, G.; Wyttenbach, T.; Bowers, M. T. Conformation of Macromolecules in the Gas Phase: Use of Matrix-Assisted Laser Desorption Methods in Ion Chromatography. Science 1995, 267, 1483-1485.

46. Chen, Y. H.; Hill, H. H.; Wittmer, D. P. Thermal Effects on Electrospray Ionization Ion Mobility Spectrometry. Int. J. Mass Spectrom. Ion Processes 1996, 154, 1-13.

47. Gillig, K. J.; Ruotolo, B.; Stone, E. G.; Russell, D. H.; Fuhrer, K.; Gonin, M.; Schultz, A. J. Coupling High-Pressure MALDI with Ion Mobility/ Orthogonal Time-of-Flight Mass Spectrometry. Anal. Chem. 2000, 72, 3965-3971. 
48. Steiner, W. E.; Clowers, B. H.; English, W. A.; Hill, H. H., Jr. Atmospheric Pressure Matrix-Assisted Laser Desorption/Ionization with Analysis by Ion Mobility Time-of-Flight Mass Spectrometry. Rapid Commun. Mass Spectrom. 2004, 18, 882-888.

49. Myung, S.; Wiseman, J. M.; Valentine, S. J.; Zoltán, T.; Cooks, R. G.; Clemmer, D. E. Coupling Desorption Electrospray Ionization (DESI) with Ion Mobility/Mass Spectrometry for Analysis of Protein Structure: Evidence for Desorption of Folded and Denatured States. J. Phys. Chem. B 2006, 110, 5045-5051.

50. Shaffer, S. A.; Prior, D. C.; Anderson, G. A.; Udseth, H. R.; Smith, R. D. An Ion Funnel Interface for Improved Ion Focusing and Sensitivity Using Electrospray Ionization Mass Spectrometry. Anal. Chem. 1998, 70, 4111-4119.

51. Kim, T.; Tolmachev, A. V.; Harkewicz, R.; Prior, D. C.; Anderson, G.; Udseth, H. R.; Smith, R. D.; Bailey, T. H.; Rakov, S.; Futrell, J. H. Design and Implementation of a New Electrodynamic Ion Funnel. Anal. Chem. 2000, 72, 2247-2255.

52. Lee, Y. J.; Hoaglund-Hyzer, C. S.; Taraszka, J. A.; Zientara, G. A.; Counterman, A. E.; Clemmer, D. E. Collision-Induced Dissociation of Mobility-Separated Ions Using an Orifice-Skimmer Cone at the Back of a Drift Tube. Anal. Chem. 2001, 73, 3549-3555.

53. Tang, K.; Shvartsburg, A. A.; Lee, H.; Prior, D. C.; Buschbach, M. A.; Li, F.; Tomachev, A.; Anderson, G. A.; Smith, R. D. High-Sensitivity Ion Mobility Spectrometry/Mass Spectrometry Using Electrodynamic Ion Funnel Interfaces. Anal. Chem. 2005, 77, 3330-3339.

54. Myung, S.; Lee, Y. L.; Moon, M. H.; Taraszka, J. A.; Sowell, R.; Koeniger, S. L.; Hilderbrand A. E.; Valentine, S. J.; Cherbas, L.; Cherbas, P.; Kaufmann, T. C.; Miller, D. F.; Mechref, Y.; Novotny, M. V.; Ewing, M.; Clemmer, D. E. Development of High-Sensitivity Ion Trap-IMS-TOF Techniques: A High-Throughput Nano-LC/IMS/TOF Separation of the Drosophila Fly Proteome. Anal. Chem. 2003, 75, 5137-5145.

55. McLean, J. A.; Russell, D. H. Sub-Femtomole Peptide Detection in Ion Mobility-Time-of-Flight Mass Spectrometry Measurements. J. Proteome Res. 2003, 2, 427-430.

56. Dugourd, P.; Hudgins, R. R.; Clemmer, D. E.; Jarrold, M. F. HighResolution Ion Mobility Measurements. Rev. Sci. Instrum. 1997, 68, 1122-1129

57. Wu, C.; Siems, W. F.; Asbury, G. R.; Hill, H. H., Jr. Electrospray Ionization High-Resolution Ion Mobility Spectrometry-Mass Spectrometry. Anal. Chem. 1998, 70, 4929-4938.

58. Srebalus, C. A.; Li, J.; Marshall, W. S.; Clemmer, D. E. Gas-Phase Separations of Electrosprayed Peptide Libraries. Anal. Chem. 1999, 71, 3918-3927.

59. Valentine, S. J.; Counterman, A. E.; Hoaglund-Hyzer, C. S.; Clemmer, D. E. Intrinsic Amino Acid Size Parameters from a Series of 113 Lysine-Terminated Tryptic Digest Peptide Ions. J. Phys. Chem. B 1999, 103, 1203-1207.

60. Shvartsburg, A. A.; Siu, K. W. M.; Clemmer, D. E. Prediction of Peptide Ion Mobilities via a priori Calculations from Intrinsic Size Parameters of Amino Acid Residues. J. Am. Soc. Mass Spectrom. 2001, 12, 885-888.

61. Valentine, S. J.; Counterman, A. E.; Clemmer, D. E. A Database of 660 Peptide Ion Cross Sections: Use of Intrinsic Size Parameters for Bona Fide Predictions of Cross Sections. J. Am. Soc. Mass Spectrom. 1999, 10, 1188-1211.

62. Mosier, P. D.; Counterman, A. E.; Jurs, P. C.; Clemmer, D. E. Prediction of Peptide Ion Collision Cross Sections from Topological Molecular Structure and Amino Acid Parameters. Anal. Chem. 2002, 74, 1360-1370.

63. Wyttenbach, T.; von Helden, G.; Batka, J. J., Jr.; Carlat, D.; Bowers, M. T. Effect of the Long-Range Potential on Ion Mobility Measurements. J. Am. Soc. Mass Spectrom. 1997, 8, 275-282.

64. Shvartsburg, A. A.; Jarrold, M. F. An Exact Hard-Sphere Scattering Model for the Mobilities of Polyatomic Ions. Chem. Phys. Lett. 1996, 261, $86-91$

65. Mesleh, M. F.; Hunter, J. M.; Shvartsburg, A. A.; Schatz, G. C.; Jarrold, M. F. Structural Information from Ion Mobility Measurements: Effects of the Long-Range Potential. J. Phys. Chem. 1996, 100, 16082-16086.

66. Clemmer, D. E.; Jarrold, M. F. Ion Mobility Measurements and their Applications to Clusters and Biomolecules. J. Mass Spectrom. 1997, 32, 577-592
67. Hoaglund-Hyzer, C. S.; Counterman, A. E.; Clemmer, D. E. Anhydrous Protein Ions. Chem. Rev. 1999, 99, 3037-3079.

68. Wyttenbach, T., Bowers, M. T. Gas-Phase Conformations: The Ion Mobility/Ion Chromatography Method. Modern Mass Spectrom. Topics Curr. Chem. Chemistry and Materials Science; Springer: Berlin/Heidelberg, 2003, 225, 207-232.

69. Study number 05-10163, Indiana University Institutional Review Board.

70. Multiple affinity removal LC column-Human 6 Agilent Technologies, http:// www.chem.agilent.com/Scripts/PDS.asp?lPage $=42367$.

71. Valentine, S. J.; Koeniger, S. L.; Clemmer, D. E. A Split-Field Drift Tube for Separation and Efficient Fragmentation of Biomolecular Ions. Anal. Chem. 2003, 75, 6202-6208.

72. Taraszka, J. A.; Kurulugama, R.; Sowell, R.; Valentine, S. J.; Koeniger S. L.; Arnold, R. J.; Miller, D. F.; Kaufman, T. C.; Clemmer, D. E. Mapping the Proteome of Drosophila Melanogaster: Analysis of Embryos and Adult Heads by LC-IMS-MS Methods. J. Proteome Res. 2005, 4, 1223-1237.

73. Collins, D. C.; Lee, M. L. Developments in Ion Mobility SpectrometryMass Spectrometry. Anal. Bioanal. Chem. 2002, 372, 66-73.

74. Wittmer, D.; Chen, Y. H.; Luckenbill, B. K.; Hill, H. H., Jr. ElectrosprayIonization Ion Mobility Spectrometry. Anal. Chem. 1994, 66, 2348-2355.

75. Valentine, S. J.; Counterman, A. E.; Hoaglund, C. S. Reilly, J. P. Clemmer, D. E. Gas-Phase Separations of Protease Digests. J. Am. Soc. Mass Spectrom. 1998, 9, 1213-1216.

76. Hoaglund, C. S.; Valentine, S. J.; Sporleder, C. R.; Reilly, J. P.; Clemmer, D. E. Three-Dimensional Ion Mobility/TOFMS Analysis of Electrosprayed Biomolecules. Anal. Chem. 1998, 70, 2236-2242.

77. Perkins, D. N.; Pappin, D. J. C.; Creasy, D. M.; Cottrell, J. S. ProbabilityBased Protein Identification by Searching Sequence Databases Using Mass Spectrometry Data. Electrophoresis 1999, 20, 3551-3567.

78. The protein database is searched using the enzyme trypsin and allowing for a single missed cleavage. A single fixed (carbamidomethyl) modification for cysteine residues is used as a search parameter. Peptides with homology scores above the identity threshold (31) are saved for map consideration

79. Hoaglund-Hyzer, C. S.; Li, J.; Clemmer, D. E. Mobility Labeling for Parallel CID of Ion Mixtures. Anal. Chem. 2000, 72, 2737-2740.

80. ${ }^{\circ}$ http://www.specialtylabs.com, ${ }^{\circ}$ Specialty ${ }^{\circ}$ Laboratories ${ }^{\circ}$ website.

81. ${ }^{\circ}$ http://www.chem.agilent.com/temp/radA4BAE/0042009.pdf, ${ }^{\circ}$ Technical notes for Agilent LC MSD TOF.

82. Keller, A.; Nesvizhskii, A. I.; Kolker, E.; Aebersold, R. Empirical Statistical Model to Estimate the Accuracy of Peptide Identifications Made by MS/MS and Database Search. Anal. Chem. 2002, 74, 5383-5392.

83. Peng, J.; Elias, J. E.; Thoreen C. C.; Licklidder, L. J.; Gygi, S. P. Evaluation of Multidimensional Chromatography Coupled with Tandem Mass Spectrometry (LC/LC-MS/MS) for Large-Scale Protein Analysis: The Yeast Proteome. J. Proteome Res. 2003, 2, 43-50.

84. Elias, J. E.; Gibbons, F. D.; King, O. D.; Roth, F. P.; Gygi, S. P. Intensity-Based Protein Identification by Machine Learning from a Library of Tandem Mass Spectra. Nat. Biotechnol. 2004, 22, 214-219.

85. Park, G. W.; Kwon, K. H.; Kim, J. Y.; Lee, J. H.; Yun, S. H.; Kim, S. I.; Park, Y. M.; Cho, S. Y.; Paik, Y. K.; Yoo, J. S. Human Plasma Proteome Analysis by Reversed Sequence Database Search and Molecular Weight Correction Based on a Bacterial Proteome Analysis. Proteomics 2006, 6, $1121-1132$.

86. Cargile, B. J.; Bundy, J. L.; Grunden, A. M.; Stephenson, J. L., Jr. Synthesis/Degradation Ratio Mass Spectrometry for Measuring Relative Dynamic Protein Turnover. Anal. Chem. 2004, 76, 86-97.

87. Bruce, J. E.; Anderson, G. A.; Smith, R. D. "Colored" Noise Waveforms and Quadrupole Excitation for the Dynamic Range Expansion of Fourier Transform Ion Cyclotron Resonance Mass Spectrometry. Anal. Chem. 1996, 68, 534-541.

88. ${ }^{\circ}$ http://www.thermo.com/eThermo/CMA/PDFs/Articles/articlesFile_ 23993.pdf, ${ }^{\circ} \mathrm{Thermo}^{\circ} \mathrm{Electron}^{\circ} \mathrm{Corporation}^{\circ}$ Application ${ }^{\circ}$ Notes.

89. ${ }^{\circ} \mathrm{http}: / /$ www.thermo.com/eThermo/CMA/PDFs/Articles/articlesFile 21825.pdf, ${ }^{\circ}$ Thermo $^{\circ}$ Electron ${ }^{\circ}$ Corporation ${ }^{\circ}$ Application ${ }^{\circ}$ Notes.

90. Derkx, F. H.; Schalekamp, M. P.; Bouma, B.; Kluft, C.; Schalekamp, M. A. Plasma Kallikrein-Mediated Activation of the Renin-Angiotensin System Does Not Require Prior Acidification of Prorenin. J. Clin. Endocrinol. Metab. 1982, 54, 343-348. 